\title{
Cancer Immunotherapy and Application of Nanoparticles in Cancers Immunotherapy as the Delivery of Immunotherapeutic Agents and as the Immunomodulators
}

\author{
Tilahun Ayane Debele ${ }^{1}\left(\mathbb{D}\right.$, Cheng-Fa Yeh ${ }^{1,2}$ and Wen-Pin Su ${ }^{1,3, * \mathbb{C}}$ \\ 1 Institute of Clinical Medicine, College of Medicine, National Cheng Kung University, No.138, Sheng Li Road, \\ Tainan 704, Taiwan; z10803012@ncku.edu.tw (T.A.D.); u802091@gmail.com (C.-F.Y.) \\ 2 Department of Internal Medicine, Chi Mei Medical Center, Tainan 710, Taiwan \\ 3 Departments of Oncology and Internal Medicine, National Cheng Kung University Hospital, \\ College of Medicine, National Cheng Kung University, Tainan 704, Taiwan \\ * Correspondence: wpsu@mail.ncku.edu.tw
}

Received: 30 November 2020; Accepted: 10 December 2020; Published: 15 December 2020

check for updates

Simple Summary: Cancer becomes one of the major public health problems globally and the burden is expected to be increasing. Currently, both the medical and research communities have attempted an approach to nonconventional cancer therapies that can limit damage or loss of healthy tissues and be able to fully eradicate the cancer cells. In the last few decades, cancer immunotherapy becomes an important tactic for cancer treatment. Immunotherapy of cancer must activate the host's anti-tumor response by enhancing the innate immune system and the effector cell number, while, minimizing the host's suppressor mechanisms. However, many immunotherapies are still limited by poor therapeutic targeting and unwanted side effects. Hence, a deeper understanding of tumor immunology and antitumor immune responses is essential for further improvement of cancer immunotherapy. In addition, effective delivery systems are required to deliver immunotherapeutic agents to the site of interest (such as: to Tumor microenvironments, to Antigen-Presenting Cells, and to the other immune systems) to enhance their efficacy by minimizing off-targeted and unwanted cytotoxicity.

\begin{abstract}
In the last few decades, cancer immunotherapy becomes an important tactic for cancer treatment. However, some immunotherapy shows certain limitations including poor therapeutic targeting and unwanted side effects that hinder its use in clinics. Recently, several researchers are exploring an alternative methodology to overcome the above limitations. One of the emerging tracks in this field area is nano-immunotherapy which has gone through rapid progress and revealed considerable potentials to solve limitations related to immunotherapy. Targeted and stimuli-sensitive biocompatible nanoparticles (NPs) can be synthesized to deliver immunotherapeutic agents in their native conformations to the site of interest to enhance their antitumor activity and to enhance the survival rate of cancer patients. In this review, we have discussed cancer immunotherapy and the application of NPs in cancer immunotherapy, as a carrier of immunotherapeutic agents and as a direct immunomodulator.
\end{abstract}

Keywords: cancer; cancer immunotherapy; nanoparticles; immunotherapeutic agent; immunomodulators

\section{Introduction}

Cancer becomes one of a killer disease and its burden is anticipated to increase worldwide due to population growth, and lifestyles changes (such as smoking, poor diet, physical inactivity) [1,2]. 
According to global cancer observatory data (GLOBOCAN), 9.6 million deaths from cancer were estimated in 2018 [3]. The widely known conventional treatment methods for cancer include surgery, chemotherapy, and radiotherapy [4]. Due to the increasing knowledge of molecular and cancer biology, a notable change was observed in cancer treatment for the last few decades. However, conventional cancer treatment has certain limitations, which urges further research investigation. Recently, different research has been underway to improve the survival rate of cancer patients which includes immunotherapy, stem cell transplantation, and targeted cancer therapies [5-10].

Herein, we briefly discuss the application of nanoparticles (NPs) in the cancer immunotherapy as the carrier of immunotherapeutic agents and as the adjuvants to stimulate immune systems to eradicate cancer.

\section{Nanoparticles and Nanoparticles-Based Drug Delivery Systems}

The majority of drugs delivered through a different route of injection, encounter the physiological, biochemical, and chemical barriers [11]. Hence, it is important to know the physicochemical and biochemical nature of the pharmaceutical agents such as solubility, permeability, and metabolic stability which are crucial factors in the design of NPs for drug delivery systems [12]. In comparison to conventional drug formulation, NPs-based drug delivery systems are under extensive development for several applications including cancer treatment due to their unique physical, chemical, and structural properties. In the last few decades, the term nanomedicine is popularized to describe the application of nanotechnology, by exploiting the unique properties of nano-scale materials, in medicine for the diagnosis and treatment of disease.

Tumor blood vessels possess special characteristics in comparison to the normal blood vessels such as uncontrolled angiogenesis, aberrant vascular architecture, hypervascular permeability, and impaired lymphatic clearance from the interstitial space of tumor tissues (i.e., enhanced permeability and retention (EPR) effect) $[13,14]$. EPR effect is a crucial point in the drug delivery systems $[15,16]$. Several kinds of the literature showed that NPs with the diameter 10-100 nm in the bloodstream are too large to escape the vasculature and enter normal tissues or to be cleared by the kidneys, while NPs can easily escape and accumulate in the tumor tissues due to dysfunctional vasculature and defective lymphatics clearance [17].

The efficacy of nanoformulated pharmaceutical agents also determined based on NPs characteristics such as sizes, shapes, and surface charge $[18,19]$. As mentioned above, NPs with a diameter range of 10 to $100 \mathrm{~nm}$ are the best candidates for cancer therapy, as they can effectively deliver their cargo and achieve EPR effect, while NPs with smaller $(<10 \mathrm{~nm})$ and larger particle size $(>200 \mathrm{~nm})$ can be easily filtered by kidneys and phagocytosed by reticuloendothelial systems, respectively [20]. However, failures of NPs-based chemotherapy in clinical trials have raised some questions about the clinical relevance of the EPR effect and much more research investigation is required to understand the tumor microenvironment (TME). In addition, ligand-modified NPs are widely explored for the active tumor targeting that can enhance bioavailability and selective tumor accumulation which in turn enhance the therapeutic efficacy while reducing normal cytotoxicity.

Moreover, shape and surface charge are crucial in cellular uptake and bio-distribution of NPs. For example, unlike spherical NPs which vulnerable to protein adsorption, non-spherical NPs show less protein adsorption and prevent non-specific cellular phagocytosis which extends their stability and half-life in circulation [21]. Another important parameter is the surface charge of NPs which has a great effect on cellular uptake and in the induction of immune response. For example, cationic NPs show good transfection effects, and have a lysosomal escape tendency which helps to release cargo in the cytoplasm or other subcellular organelles [22]. However, due to their cationic nature, they adsorb more negatively charged serum proteins which hinders their bioavailability [23,24]. As the result, NPs are coated with hydrophilic materials such as polyethylene glycol (PEG), or polysaccharides such as dextran to minimize protein corona, which in turn enhance circulation half-life and its bioavailability [25-27]. 
NPs-based drug delivery shows a promising result in preclinical and clinical studies. Currently, approximately 50 nanopharmaceuticals agents are approved for cancer and other disease treatments by US FDA [28-30]. However, some nanomedicine products that have undergone extensive clinical trials were later withdrawn due to efficacy or safety concerns e.g., superparamagnetic iron oxide formulations Resovist and SINEREM [31,32].

\subsection{The Application of Nanoparticles in Cancer Immunotherapy}

The idea of cancer immunotherapy is boosting the antitumor activity of immune systems via tumor-specific immune activation or non-specific immune activation [4,33-36]. The cancer immunotherapy can be boosted via: (a) Increasing antigens presentation and induce specific cytotoxicity T-lymphocytes (CTLs) activity [37]. Naive $\mathrm{CD}^{+} \mathrm{T}$ cells activated and induced antitumor immune response when their receptors recognize antigens presented by Antigen Presenting Cells (APCs) (such as DC) in the context of MHC-I molecules [38,39]. Activated CTLs secrete several cytokines such as interferon-gamma (IFN- $\gamma$ ), tumor necrosis factor-alpha (TNF- $\alpha$ ) and the crucial cytolytic mediators (perforin, granzyme, etc.), which improve antigen presentation and mediate anti-tumor effects [40]. (b) Guiding T-cells to the tumor using a bispecific Antibody (bAbs). bAbs offers a unique opportunity to redirect specific immune effector cells to kill cancer cells [41,42]. bAbs can bind simultaneously two different antigens or epitopes to guide T cells to tumor cells, to inhibit two different signaling pathways, and to deliver cargos to the targeted sites [43]. (c) The downregulation of Treg cell, or MDSCs. The TME is enriched with cellular and acellular components that negatively influence cancer immunotherapy [44,45]. MDSC and Treg cells are major components of the immune-suppressive TME and promote T-cell dysfunction that in turn favors tumor progression [46,47]. Hence, downregulation of Treg cell or MDSCs via administration of specific antibodies for each cell is crucial in cancer immunotherapy [48-51].

Immunotherapy offers numerous advantages in comparison to the conventional standard cancer treatment available nowadays [52,53]. Of those, when appropriately stimulated, tumor-specific immune cells can target a microscopic disease, disseminate metastasis, and long-term control might completely remove cancer due to the memory cells [54-56].

Although immunotherapy is efficient to treat different types of cancer, still there is a certain challenge in delivery of immunotherapeutic agents which is expected to be resolved using NPs [57]. A major goal of the utilization of NPs in cancer immunotherapy is to improve therapeutic index by enhancing deliver of immunotherapeutic agents directly to the site of interests only, enhancing accumulation and potency at a region of interest, while simultaneously minimize the dose-dependent systemic toxicity [58]. Unlike delivering chemotherapeutic agents to tumor cells, which necessitates a high dose of nanoformulated drugs to kill all the target cells to be effective, lower concentrations of immune-stimulating drugs can be used to initiate an immune cell or organs (such leukocytes or lymphoid organs) response [59]. For example, Schmid et al. developed antibody-targeted NPs that bind to $\mathrm{CD} 8^{+} \mathrm{T}$ cells in the blood, lymphoid tissues, and tumors of mice [60]. Synthesized NPs encapsulated with a SD-208, TGF $\beta R 1$ inhibitor, or a TLR7/TLR8 agonist. Both in vitro and in vivo mice studies showed, successful targeting of PD-1+ $\mathrm{T}$ cells in the circulation and in the tumor. Compared to the free drugs, NPs-encapsulated SD-208 enhances survival of mouse bearing colorectal cancer. In addition, synthesized NPs enabled PD-1-targeted delivery of a TLR7/8 agonist to the TME and tumor-infiltrating $\mathrm{CD}^{+} \mathrm{T}$ cells were increased. Overall, this result shows that targeting tumor-infiltrating immune cells in the blood, rather than direct tumor cell targeting, is a better way to improve immunotherapeutic localization in tumors and to stimulate an antitumor response.

In summary, NPs based cancer treatment has a numerous advantage compared to conventional cancer therapy due to: (1) Nanoscale size with several surface characteristics to enhance drug accumulation at the site of interest via EPR effects, (2) Target tumor cells via active targeting which will minimize off-target normal cell toxicity, (3) Protect a therapeutic payload (such as protein, gene, small peptide) from biological degradation, (4) Enhance solubility of hydrophobic drugs and improves 
there bioavailability, (5) enhance in vivo stability and bioavailability, (6) prevents premature drug release, (7) used as theranostic, combined imaging and therapeutic applications and (8) stimuli, internal or external, programmed to release its cargo at the site of interest.

Furthermore, due to their effectiveness at eliciting cellular and humoral immune responses, NPs can be designed to activate the immune system that could form a gorgeous basis for cancer vaccine development $[61,62]$. As the result, several NPs are synthesized to deliver different types of immunotherapeutic agents to enhance their therapeutic efficacy, and some of them already shown satisfactory results in clinical trials [63].

\subsubsection{Nanoparticles as the Carrier of Immunotherapeutic Agents}

Over the last few decades, numerous studies and a large number of papers (Figure 1) have been published on nano-based therapies for cancer treatments. In the last two decades, the total number of papers related to 'nanoparticle + immunotherapy' on PubMed approximately doubled every two years which will be expected a rise similarly in the future.

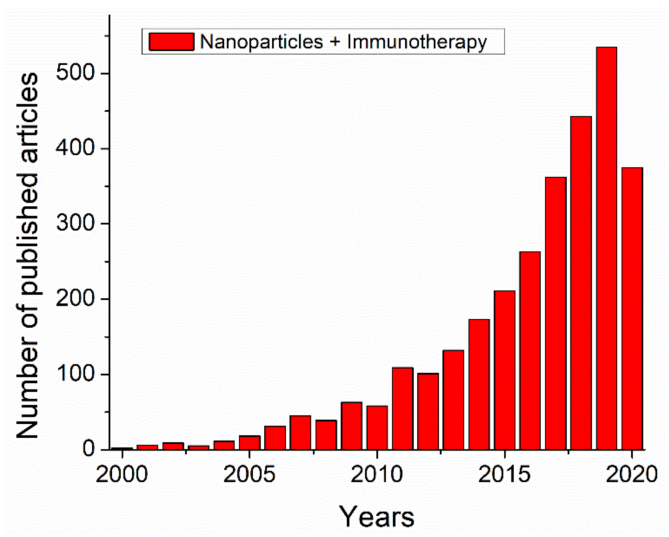

Figure 1. A number of published papers for the last two decades (i.e., 2000-2020) by searching on PubMed using key words "nanoparticles + immunotherapy".

NPs should be precisely designed to target region of interest preferentially from site of administration (common vaccine administration routes are mucosal or parenteral) in order to enhance the efficacy of immunotherapeutic agents $[64,65]$. NPs targeting lymphoid tissues, where the majority of immune cells are concentrated, would enhance the efficacy of immunotherapeutic agents due to direct access to immune cells [66-69].

Depending on their physicochemical characteristics, including particle size, hydrophobicity, shape, and surface charge, NPs can directly drain to the nearest lymph node, or stay in the injection site and attract migratory DC or macrophages [70]. Several kinds of the literature show that NPs with particle sizes $>100 \mathrm{~nm}$ tend to form depot and taken up by APCs and then draining to lymph nodes [71,72]. However, NPs with moderate particle size $<100 \mathrm{~nm}$ drained to lymph nodes via lymphatics and retained relatively for a long time, while NPs with small particle size $(<10 \mathrm{~nm})$ drain to blood capillaries [73,74]. Regarding the surface charge, negatively charged NPs drain to the lymph node was reported due to charge repulsion with negatively charged ECM, while, cationic NPs tend to form a depot, taken up by peripheral and migratory APCs or gradually draining to lymph node [75]. NPs with nearly neutral charge exhibited potential vector for tumor antigen because they targeted the draining lymph nodes after subcutaneous injection. However, they were weakly immune-stimulatory. In addition, the presence of PEG (PEGylation) on Surface of NPs significantly enhanced large particle size ( $200 \mathrm{~nm})$ drain to lymph node and uptake by DCs [76].

Moreover, targeted and stimuli sensitive biocompatible NP can be synthesized to deliver immunotherapeutic agents' in their native conformations to increase antigen uptake, processing, and presentation. For example, NPs can be synthesized for facilitating the cytosolic delivery of antigens, 
increasing cross-presentation via the MHC-I pathway, and thus inducing cytotoxic T-cell responses. In addition, in the drug delivery system, it is possible to load or conjugate two or more than two drugs in the single nanocarriers as the co-delivery which will minimize dose related toxicity and enhance the activation of the immune response. For example, Song et al. developed the combined delivery of immunogenic chemotherapy and PD-L1 trap fusion protein using liposomal NPs [77]. They reported that PD-L1 trap is produced transiently and locally in the TME and oxaliplatin (OxP) boosts anti-PD-L1 therapy against murine colorectal cancer and exhibited reduced toxicity compared with non-nanoformulated ones (i.e., free PD-L1 antibodies and oxaliplatin).

In general, NP based drug delivery systems encompass a wide variety of nano-scale size materials including inorganic and Organic NPs in different forms [16].

\subsubsection{Antigens and Adjuvants Delivery to Antigen Presenting Cells (APCs)}

APCs used as the link between innate and adaptive immune responses by interacting with $\mathrm{T}$ cells [78]. APCs are primarily used to recognize and present tumorigenic antigens on their surface via MHC complexes to $\mathrm{T}$ cells to initiate an effective adaptive response [79]. However, due to enzymes susceptible of antigens in the body, they are not easily transferred to APCs which decreases its immunogenicity. Hence by using NPs it is possible to overcome this limitation. NPs can encapsulate and deliver cancer antigens to APCs without tumor antigen degradation by the intracellular enzyme. In addition, nanoformulated antigens are more efficiently taken up and processed by APCs than soluble vaccines to amplify T-cell responses due to intradermally or subcutaneously injected NPs drain to lymph nodes, in which APCs are in closeness to T cells [80].

Shen et al. encapsulated ovalbumin (OVA) antigen in the PLGA and deliver successfully to primary mouse bone marrow-derived dendritic cells (BMDCs) [81]. Their result showed that the MHC class I presentation of PLGA-encapsulated OVA stimulated T cell IL-2 secretion at a 1000-fold lower concentration than soluble antigen and 10-fold lower than antigen-coated latex beads.

Kranz et al. precisely designed RNA-lipoplexes (RNA-LPX) NPs with the particle size of 200-320 nm, by optimally adjusting lipid: RNA ratio to precisely target DC using intravenous injection (Figure 2) [82]. The lipoplexes protect antigen-encoding RNA degradation by ribonucleases. In addition, RNA-LPX enhances cellular uptake and expression of the encoded antigens. Moreover, two transient waves of IFN- $\alpha$ were observed after the NP vaccine injection that led to better T-cell responses and produced vigorous and long-term antitumor effects.

Several kinds of literature showed that the targeted delivery of NPs formulated antigen into DC would enhance antigen presentation to T cells [83-86]. For example, Cruz et al. designed Pegylated PLGA NPs functionalized with TLR3/7 ligand to encapsulate OVA to target surface receptors of DC (i.e., CD40, DEC-205, and CD11c) to accomplish an effective cytotoxic T cell response [87]. In vitro cellular uptake study showed that TLR3/7 ligand targeted NP was more taken up by DC compared to non-targeted NP. Furthermore, high expression of IL-12, IFN- $\gamma$, and co-stimulatory molecules were observed in the ligand targeted NP in comparison to non-targeted NPs. Moreover, in vivo vaccination studies showed that ligand targeted NP consistently showed higher efficacy than non-targeted NP in stimulating $\mathrm{CD} 8^{+} \mathrm{T}$ cell responses.

Some research finding shows that immune response will be enhanced by co-delivering of adjuvants along with tumor antigens due to efficient antigen cross-presentation and vigorous T-cell response for tumor immunotherapy [88-91]. For example, Kuai et al. synthesized high-density lipoprotein-mimicking nanodiscs for co-delivery of $\mathrm{CpG}$ adjuvant and neoantigens [92]. They reported that, synthesized nanodiscs elicited up to 47-fold greater frequencies of neoantigen-specific CTLs than soluble vaccines and 31-fold greater antigen-specific T-cell response compared to Montanide. Moreover, nanodiscs in combination with anti-PD- 1 and anti-CTLA-4 therapy revealed better eradication of established cancer cells. 
A

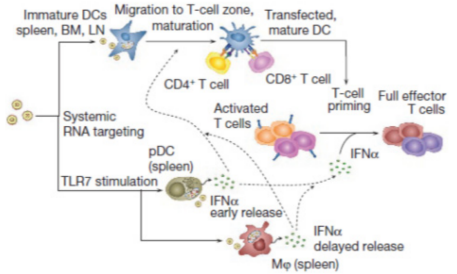

B

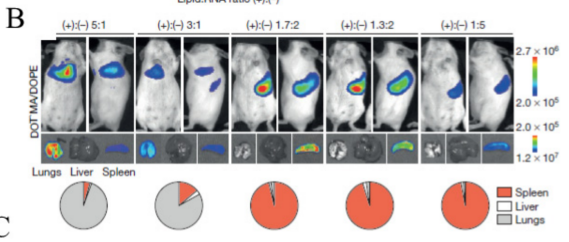

$\mathrm{C}$

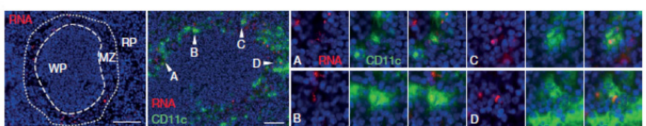

$\mathrm{D}$

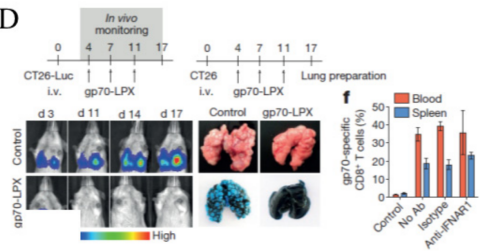

E $\quad d 1(7.2 \mu \mathrm{gg} \cdot \mathrm{d} 8(14.4 \mu \mathrm{g}) \cdot \mathrm{d} 15(29 \mu \mathrm{g})$

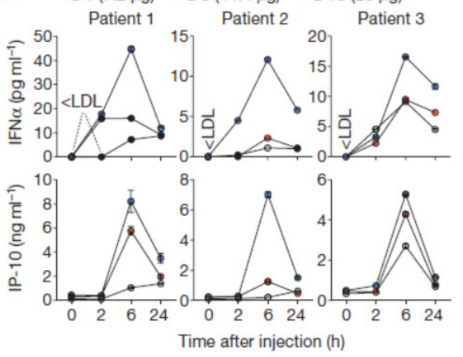

Figure 2. RNA-lipoplexes (RNA-LPX) delivery to DCs. (A) Mechanism action of RNA-LPX to induce anti-tumor immune responses, (B) Bioluminescence imaging of BALB/c mice, (C) Splenic localization of CD11c and Cy3 double-positive cells in BALB/c mice after $1 \mathrm{~h}$ of Cy3-labelled RNA-LPX i.v. injection, (D) in vivo studies in CT26 tumor bearing BALB/c mice immunized with gp70-LPX, and (E) Clinically administered RNA-LPX vaccines induce systemic INF $\alpha$ in dose-dependently manner. Reproduced with permission from [82]. Copyright 2016, Springer Nature.

Similarly, Liu et al. have been synthesized cell-penetrating peptide (CPP) decorated uniform-sized pristine NPs to deliver GM-CSF and IL-2 into tumor cells [93]. In vitro and in vivo (Figure 3) results revealed the programed promotions of multi-adjuvants on DC recruitment, antigen presentation, and T-cell activation. Furthermore, in vivo assessments revealed the satisfactory effects on tumor growth suppression, metastasis inhibition, and recurrence prevention.
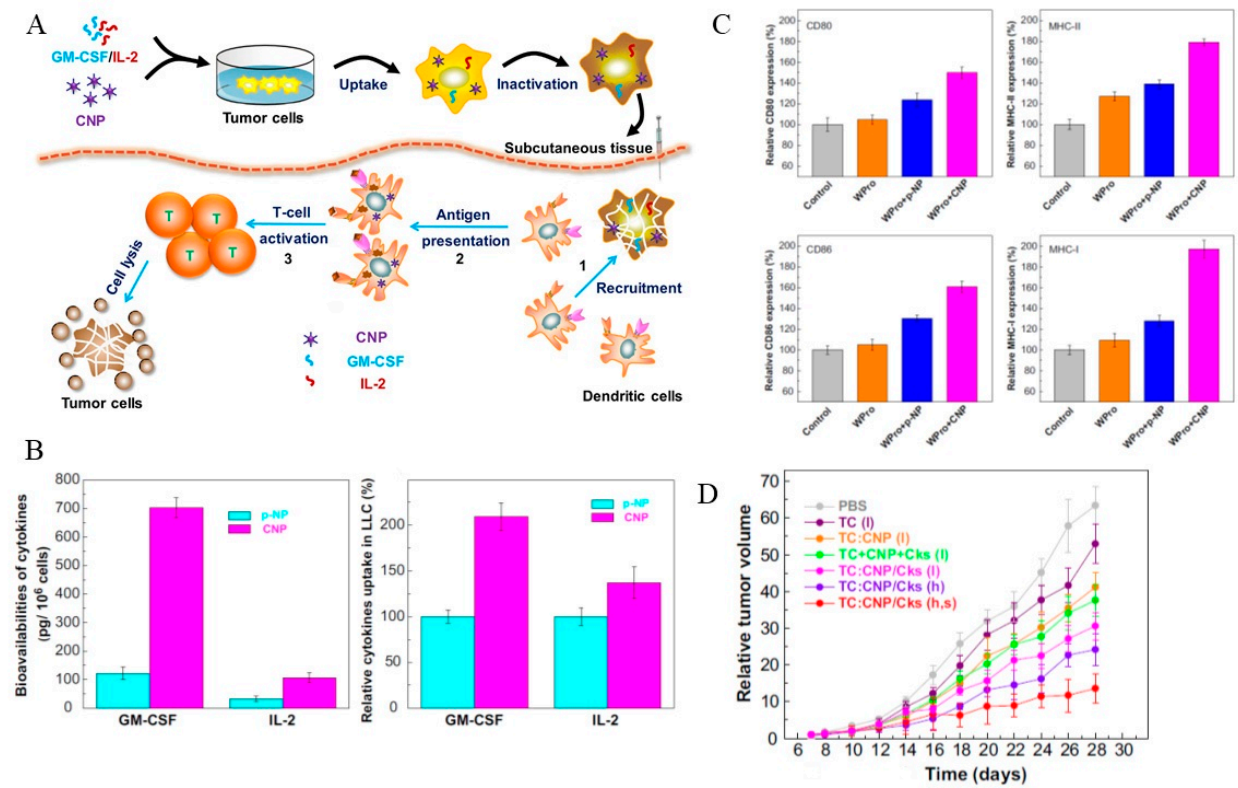

Figure 3. (A) Scheme of multi-adjuvant WCTV to initiate anti-tumor immunity, (B) bioavailability and cellular up take of GM-CSF and IL-2 in LLC cells after incubating with nanoparticles (NPs) for $24 \mathrm{~h}$, (C) relative expressions of CD80, CD86, MHC II, and MHC-I molecules after treatment with whole tumor cell lysate protein (WPro), p-NP, and CNP for $24 \mathrm{~h}$ and (D) Relative tumor volume of LLC tumor bearing mice after immunization with multi-adjuvant WCTVs compared with other vaccine groups. Reproduced with permission from [93]. Copyright 2013, Elsevier Ltd. 


\subsubsection{Antigens and Adjuvants Delivery to Tumor Microenvironment (TME)}

The TME comprised proliferating tumor cells, the tumor stroma, infiltrating inflammatory cells, apoptotic cancer cells, cancer-associated fibroblasts, myeloid-derived suppressor cells, tumor-associated macrophages, and a variety of associated tissue cells which are participating in the suppression of antitumor immunity [94]. These immunosuppressive cells secrete numerous soluble mediators including, Transforming growth factor-beta (TGF- $\beta$ ), Indoleamine 2,3-dioxygenase (IDO), arginase, prostaglandin E2 and nitric oxide synthase 2 (NOS2) [95-97]. By reducing the supply of indispensable amino acids (such as arginine (R) and Tryptophan (W)), IDO and arginase directly suppress T cell proliferation and differentiation [98]. The activity of arginase and IDO translates not only into amino acid deprivation but also in the production of metabolites (such as L-kynurenine and spermidine) capable of numerous physiologic effects $[99,100]$. For example, L-kynurenine derived from $W$, favors the differentiation of Treg cells and induces IDO expression in DCs. Similarly, TGF- $\beta$ also alters activation, maturation, and differentiation of DCs, $\mathrm{CD} 4^{+}$, and $\mathrm{CD} 8^{+} \mathrm{T}$ cells. In addition, PD-L1/PD-L2 expressed on tumor cells can engage PD-1 receptor on the surface of activated T cell and sends inhibitory signals via activating phosphatases, resulting in dephosphorylation of key elements in the $\mathrm{T}$ cell, leading to down-regulating proliferation, survival, and cytokine production [101]. Furthermore, the CTLA-4 receptor on tumor cells binds to co-stimulatory molecules on DCs and decreases antigen presentation. Moreover, there are an abundant accumulation of acellular components such as fibrosis, collagen, secreted protein acidic and rich in Cysteine (SPARC), and hyaluronan which alters the physicochemical properties of TME (including physical barriers, physical pressure (i.e., increase interstitial fluid pressure, change in metabolism, etc.) [102].

As mentioned above, although several immune effector cells are recruited to the TME, their anti-tumor activity is suppressed principally in response to tumor-derived signals [103]. Compared with normal tissue, TME has some unique characteristics, such as vascular abnormalities, hypoxia, increases in proteolytic activity, and an acidic microenvironment, which leads to treatment resistance [104]. Therefore, new approaches are demanded to overcome TME related immunosuppressive situations. Hence, targeting immunosuppressive cells (such as Treg) or Tumor-associated macrophage (TAM) in the TME using NPs could be the best tactics to prevent immunosuppression.

Sacchetti et al. designed ligand guided PEG-modified single-walled carbon nanotubes (PEG-SWCNTs) to target Treg-specific receptors in the TME [105]. They found that ligand targeted PEG-SWCNTs were preferentially up taken by Treg cell residing in the TME via glucocorticoid-induced TNFR-related receptor (GITR).

Similarly, Zhu et al. synthesized mannose targeted PEG-sheddable NPs to target TAM [106]. They reported that mannose-modified PEG-sheddable NPs was effectively targeted TAMs via the mannose-mannose receptor. As a result, more PEG-sheddable NPs accumulation was observed in TAM in comparison to non-sheddable PEG. This is maybe due to PEGylation which minimizes NPs opsonization and enhances its bioavailability.

In addition, NPs can be used to deliver anti-immunosuppressive factors, such as anti-TGF- $\beta$ or TGF- $\beta$ receptor inhibitor to the TME to increases the activation of the immune system. Park et al. synthesized liposomal polymeric gels (nLGs) to deliver IL-2 and TGF- $\beta$ inhibitors (Figure 4) [107]. The author reported that IL-2 and TGF- $\beta$ inhibitors were successfully delivered to the TME. In vivo results showed that nLGs treatment suppresses a tumor growth, improved survival rates, and enhanced the activity of NK cells and intratumoral-activated CD8 ${ }^{+}$CTLs.

In summary, NPs can enhance anticancer immunity by regulating the TME either by inhibiting immunosuppression or by endorsing immune activation which could synergize with clinically established immunotherapeutic agents such as Immune Checkpoint Inhibitors (ICIs). Hence, targeting immune cells in the TME using nanoformulated therapeutic agents is the best tactic to activate antitumor immunity. 

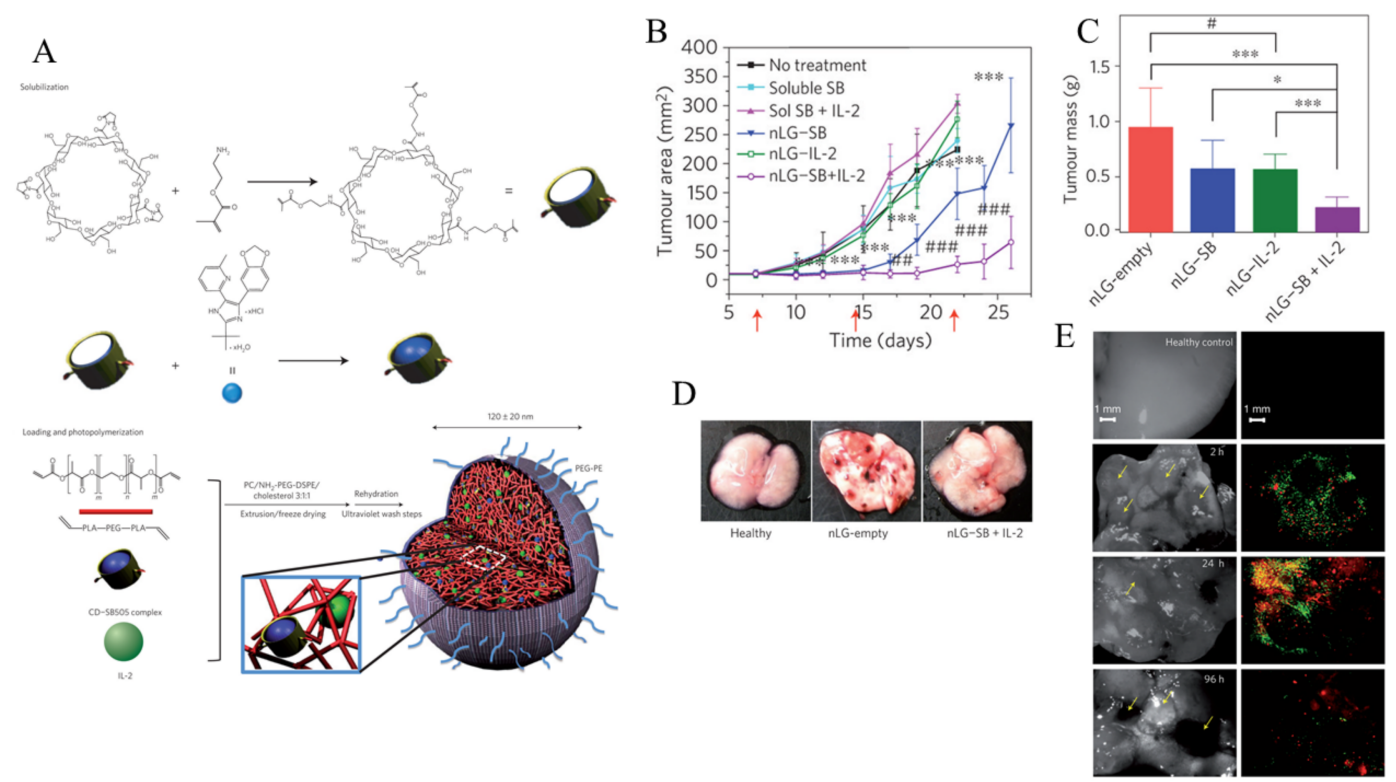

Figure 4. (A) The synthesis approach of the liposomal polymeric gel (nLG) particle system. (B) Plot of tumor area versus time. Red arrows indicate treatments (via intratumoral injection). $\left(p<0.05,{ }^{*}, p<0.001,{ }^{* * *}\right.$, By ANOVA with Turkey's multiple comparison test. $p<0.05$, \#, by two-tailed t-test. (C) Tumor masses vs nLG-treated groups, $p<0.001,{ }^{* * *}, p<0.01,{ }^{* *}, p<0.05,{ }^{*}$, By ANOVA using Turkey's post-test. (D) Images of lung immediately before collection of lung-infiltrating lymphocytes from mice, (E) Uptake of lipid carrier (green) and rhodamine payload (red) around individual lung tumors at $2 \mathrm{~h}$ post injection. Reproduced with permission from [107]. Copyright 2012, Nature Publishing Group.

\subsubsection{Immune Checkpoint Inhibitors (ICIs) Delivery}

Immune checkpoints are surface proteins on immune cells that act as negative regulators of immune activation by various antigens, including tumor antigens [108]. Immune checkpoint molecules include PD-1, PD-L1/2, CTLA-4, T-cell immunoglobulin and mucin domain-containing-3 (TIM-3), and lymphocyte-activation gene 3 (LAG-3) $[109,110]$. Immune checkpoint molecules are widely expressed on both tumor cells and immune cells, which might be negatively regulated by tumor-specific T cells via receptor-ligand interactions, causing T-cell anergy or exhaustion [111,112]. Tumor cells evade destruction from the immune system by triggering immune checkpoint receptors, such as CTLA-4, PD-1, or PD-L1, that are expressed on T-cells and whose engagement inhibits T-lymphocyte function [113].

ICIs are monoclonal antibody that inhibits the receptors-ligands interaction and enhance immune-mediated cancer eradication. The development of ICIs lays a key foundation in cancer immunotherapy [114]. In 2018, James P. Allison and Tasuku Honjo were awarded a Nobel prize in physiology or medicine for the discovery of cytotoxic T-lymphocyte-associated antigen (CTLA-4), and programmed cell death protein 1/programmed cell death protein ligand 1 (PD-1/PD-L1), respectively [115]. According to literature report, anti-CTLA-4 antibody overcomes a block in essential costimulatory signals (i.e., CTLA-4 and CD28 competes for the same ligands CD80 and CD86; CTLA-4 has a higher affinity than CD28) that are required for activation of both naive T cells and resting clones, whereas PD-1/PD-L1 blockade seems to remove a barrier and enable T cell effector function at the tumor site [116,117]. As the result, ICIs including anti-CTLA-4 and anti-PD-1/PD-L1 Abs were developed to block these inhibitory pathways [118-120]. Currently, some of the ICIs including the anti-CTLA-4 agent, ipilimumab, Tremelimumab; anti-PD-1 agents, nivolumab and pembrolizumab; and anti-PDL-1 agent, Atezolizumab, Avelumab, Cemiplimab, Durvalumab, ipilimumab, and atezolizumab [121-123] have been approved for the treatment of certain types of cancer [124]. Mechanism action of ICIs are briefly summarized in Figure 5, [124]. Furthermore, in their 
current review paper, Vaddepally et al. have been briefly reviewed the majority of FDA-approved ICIs per national comprehensive cancer network guidelines [125].

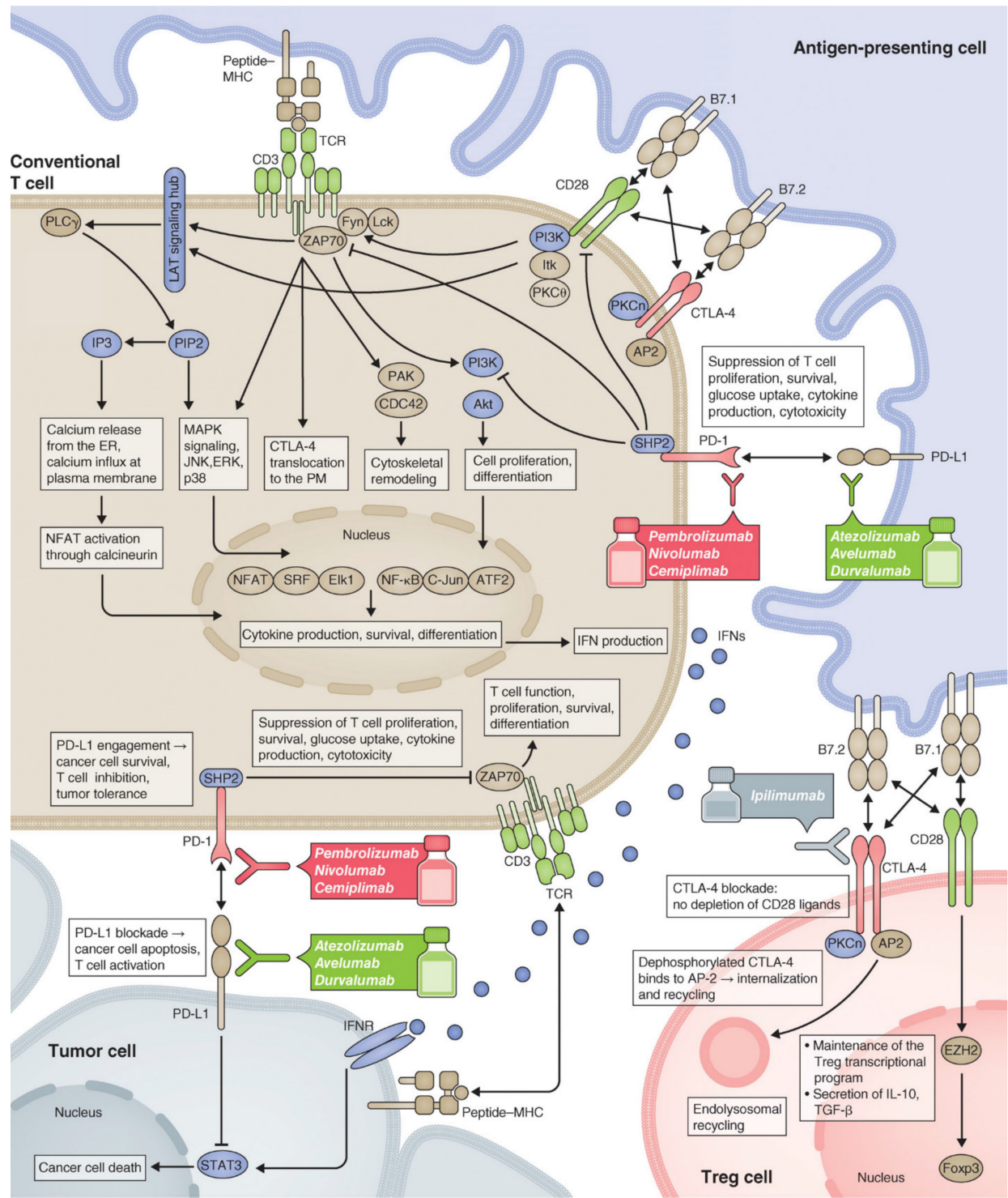

Figure 5. Mechanism action of Immune Checkpoint Inhibitors (ICIs). Reproduced with permission from the Journal of Cell Biology [124].

Even though a promising clinical data was obtained using ICIs, still, it shows certain limitations including an occurrence of immune-related adverse events, low response rate, and acquired resistance which is expected to be improved using NPs.

Wang et al. designed $\mathrm{pH}$-sensitive microneedle (MN) patch for the sustained delivery of anti-PD1 (aPD1) (Figure 6) [126]. Glucose oxidase was used to generate acidic environments by converting glucose to glucuronic acid, leading to NPs self-dissociation, which in turn facilitates sustained aPD1 releases. The authors found that, at the same dose, $\mathrm{pH}$-sensitive $\mathrm{MN}$ patch induces more immune responses compared to non-sensitive MN or free aPD1 using B16F10 mouse melanoma model. Furthermore, the author demonstrated that the aCTLA-4 and aPD1 co-loaded in MN patch shows synergistic effects.

Similarly, Wang et al. have been designed inflammation-triggered CpG DNA-based "nano-cocoons" for co-delivery of anti-PD-1 Ab and CpG oligodeoxynucleotides (CpG ODNs) (Figure 7) [127].The author 
reported that in comparison to free $\mathrm{CpG}$ nucleotides and aPD1, bioresponsive controlled release of CPG and aPD1 showed a considerable immune response and better therapeutic efficacy.

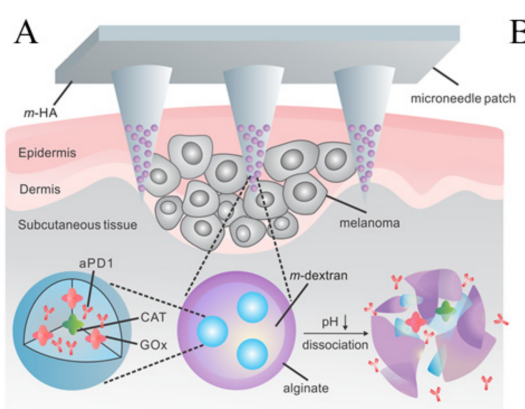

C

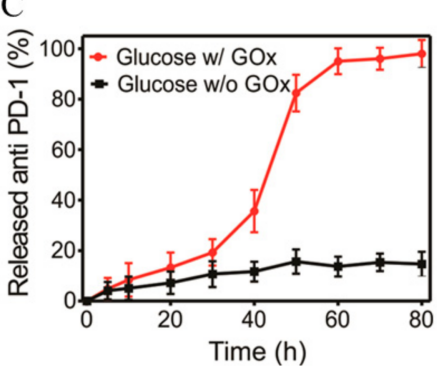

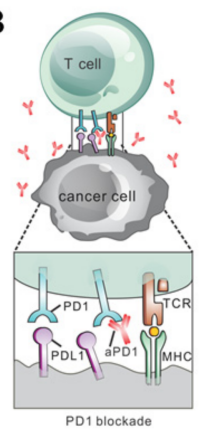

$\mathrm{E} \widehat{\mathrm{B}}$

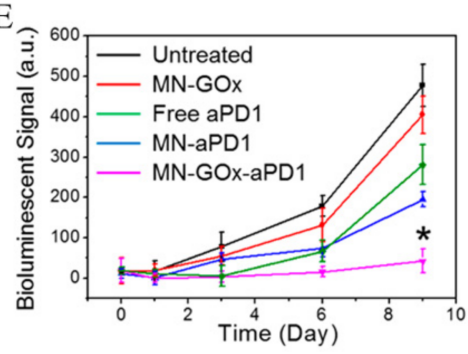

$\mathrm{D}$

Day 0
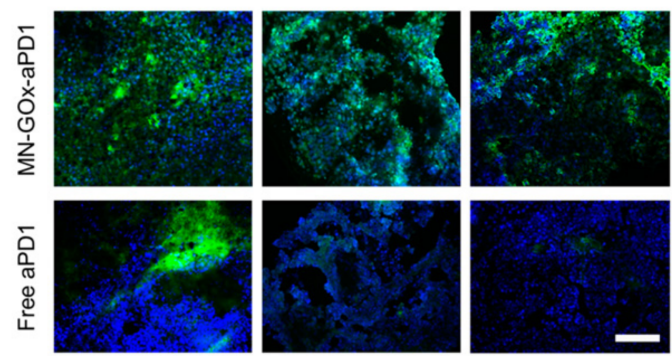

Day 1

Day 3

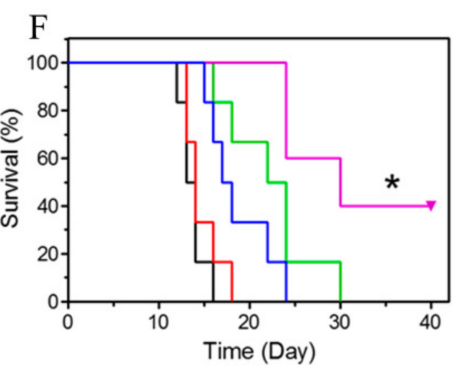

Figure 6. (A) Scheme of aPD1 delivery via microneedle (MN) patch, (B) Mechanism action of aPD1 to activate T-cell, (C) aPD1 release (\%) from the MN patches in the presence of $100 \mathrm{mg} / \mathrm{dL}$ glucose solution at $37^{\circ} \mathrm{C}$, (D) Immunofluorescence staining of tumors treated with MN-GOx-aPD1 or free aPD1 at different time points (green: aPD1, blue: nucleus), (E) Bioluminescence signals vs. time after treatment with different groups, and (F) \% Survival plot of mice after MN patch-assisted delivery of aPD1 therapy. P value: ${ }^{*}, p<0.05$. Reproduced with permission from [126]. Copyright 2016, American Chemical Society.

a

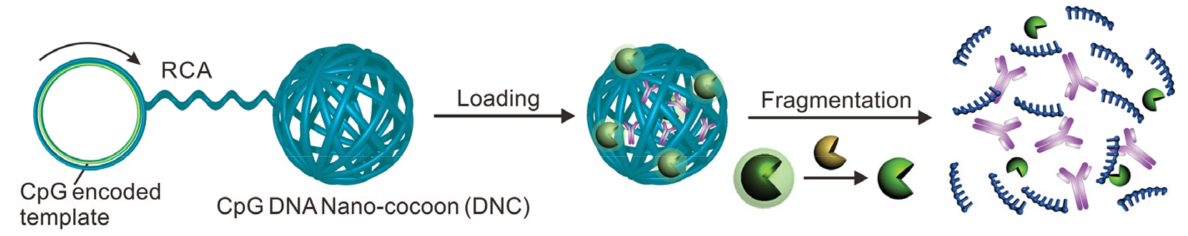

Restriction enzyme

Caged enzyme by TGMS $Q$ Proteolytic enzymes

CpGODN YaPD1

b
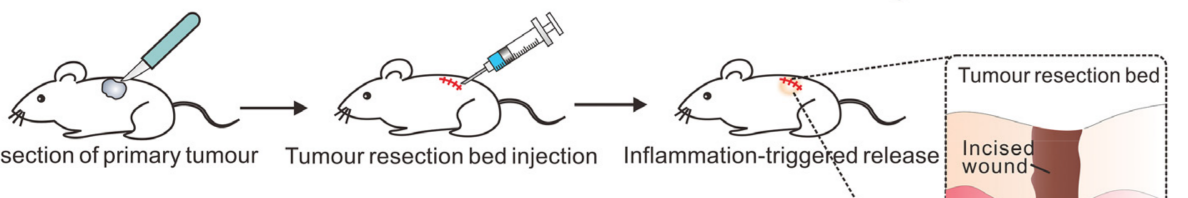

C
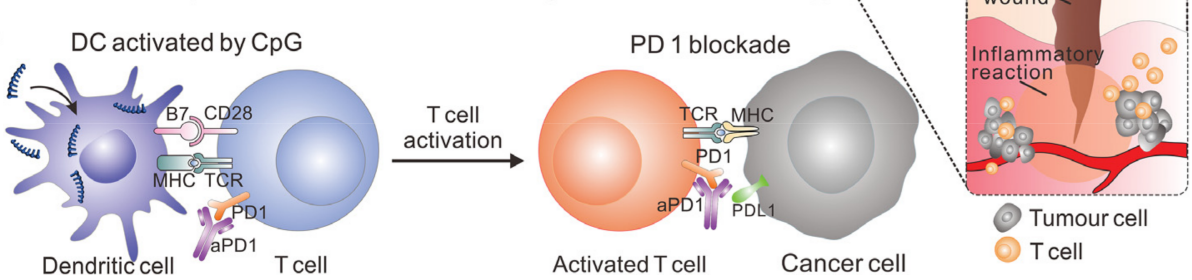

Figure 7. Schematic illustration of (a) aPD1 and caged restriction enzyme loaded DNA nanococoon (DNC), (b) In vivo tumor immunotherapy after primary tumor resection, local injection, and treatment of DNC-based delivery system and (c) Activation of DCs by CpG which in turn activates T cell response with aPD1 for PD 1 blockade. Reproduced with permission from [127]. Copyright 2016, WILEY-VCH Verlag GmbH \& Co. KGaA, Weinheim. 
Several researchers reported that patients with advanced cancer poorly respond to PD1/PD-L1 inhibitory therapy due to low TAA expression [128,129]. Epigenetic alteration like DNA hypermethylation, which is commonly seen at TAA promoter regions, plays an essential role in immune evasion of cancer cells during tumorigenesis [130]. Hence, epigenetic modulators, such as hypomethylation agents (HMAs), play a key role in the induction of TAA expression, which in turn increase antitumor immune response [131]. Ruan et al. synthesized a $\mathrm{pH}$ and reactive oxygen species (ROS) sensitive bioresponsive gel depot for co-delivery of aPD1 and Zebularine (Zeb), HMA [132]. The author reported that combination therapy enhances the immunogenicity of cancer cells and plays a crucial role in converting immunosuppressive TME.

Preclinical animal studies using cancer nanovaccines, nanoformulated TAA, or tumor-specific neoantigens, revealed promising therapeutic efficacy [133]. However, the clinical use of these nanovaccines has been limited due to immune evasion and suppression in the TME [134,135]. Some literature showed that high expression of immune checkpoints such as PD-L1 is responsible for the occurrence of tumor resistance to vaccine-mediated immune responses. Hence, it possible to overwhelm this limitation by combining with ICIs such as anti-PD-1, anti-PD-L1 or anti-CTLA4 Ab.

Kim et al. developed a small lipid nanoparticle (SLNP)-based nanovaccines embedded with antigen/adjuvant (OVAPEP-SLNP@CpG), Figure 8 [136]. Synthesized nanovaccine showed high potent antitumor efficacy in both prophylactic and therapeutic E.G7 tumor models but induced T cell exhaustion by increasing PD-L1 expression, leading to tumor recurrence. However, by using mice that showed a good therapeutic response after the first cycle of immunization with the nanovaccine the author underwent a second cycle together with anti-PD-1 therapy. Their result revealed tumor relapse of suppressed, treatment sequence, and the timing of each modality is crucial in order to enhance antitumor efficacy using combinations of nanovaccines with ICIs.

A

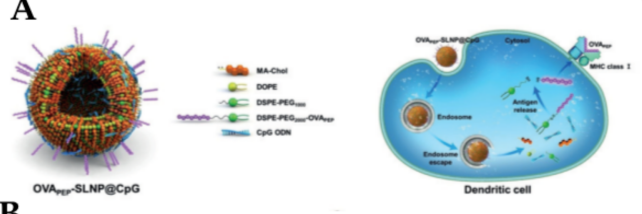

B

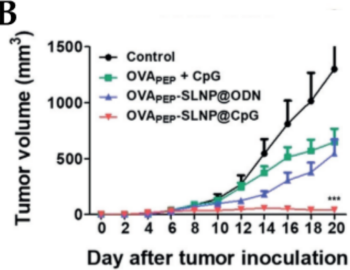

C

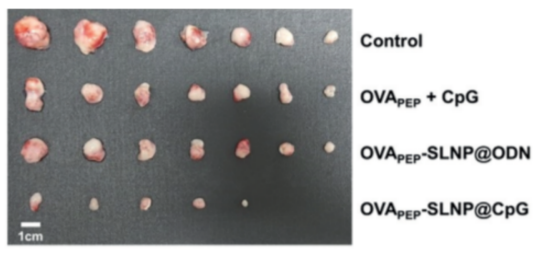

D

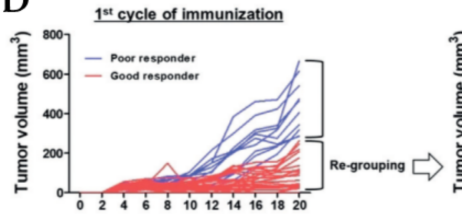

Days after tumor inoculation
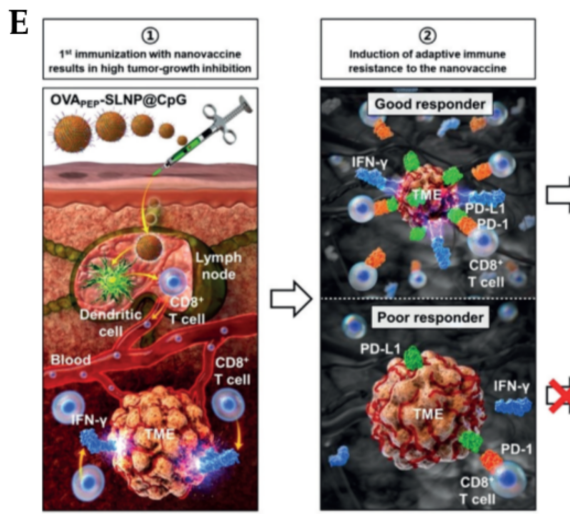

$2^{\text {nd }}$ cycle of immunization

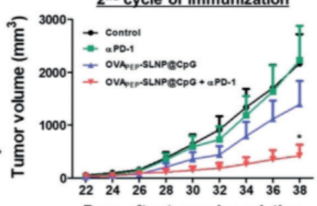

Days after tumor inoculation.

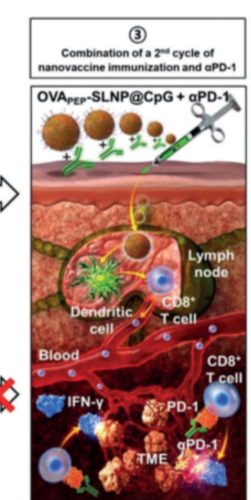

Figure 8. (A) Scheme and mechanism action of OVAPEP-SLNP@CpG nanovaccine, (B) Therapeutic

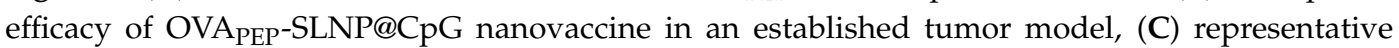
image of tumors. Scale bar $=1 \mathrm{~cm}$, (D) First cycle and second cycle of immunization, (E) Overall process of sequential and timely combination strategy between cancer nanovaccine. $p<0.001, * * *$, $p<0.05,{ }^{*}$, Reproduced with permission from [136]. Copyright 2020, Wiley-VCH Verlag GmbH \& Co. KGaA, Weinheim.

Similarly, Fontana et al. have designed and assessed biohybrid nanovaccines in combination with anti-CTLA4 antibody [137]. The author observed, an increased activation of APCs and increased priming of $\mathrm{CD} 8^{+} \mathrm{T}$ cells after nanovaccine injection. Most interestingly, treatment efficacy was increased 
(87.5\% of the animals responding, with 2 remissions) in the co-administration (nanovaccine with anti-CTLA4 antibody) compared to the checkpoint inhibitor alone in the B16.OVA model.

\subsubsection{Nanoparticles as the Direct Immunomodulators}

Immunomodulatory compounds such as cytokines, monoclonal antibodies and adjuvants have been used to reshape the TME and to initiate anti-tumor immunity; although there are certain limitations such as therapeutic efficacy and unwanted side effects during systemic administration, to use in clinics [138].

Immunomodulatory NPs can readily improve the therapeutic effects by enhancing immune stimulation and minimizing off-target side effects. As the result, more research works are undergoing to understand the mechanisms of NPs-Immuno-interactions which is highly important to know the immunomodulating potential of NPs, as the immunostimulating or as immunosuppression [139]. The function of NP in the immunomodulation depends on several factors that are intrinsic to NPs, such as surface chemistry, charge, size, and shape, besides extrinsic factors such as route of administration [140].

Several researchers have widely explored the immunomodulating effects of both polymeric and inorganic NPs $[28,141,142]$. Different evidence suggests that the immune system cells interact with NPs through Toll-like receptors (TLRs) [143,144]. TLRs are transmembrane proteins, expressed on APCs such as DCs and macrophages, which recognize specific molecular patterns that act as danger signals to the immune system [145]. Depending on the type of receptor and the type of stimuli, TLR engagement plays a great role both in the innate and adaptive immune response by altering several gene expressions.

Inorganic NPs such as Gold nanoparticles (AuNP), Titanium nanoparticles (TiNPs), iron nanoparticles (FeNPs), Zinc nanoparticles (ZnNPs), and silver nanoparticles (AgNPs) are the most stable and promising particles to modulate immune systems [146-148].

Vasilichin et al. investigated the influence of metal oxide NPs on innate immunity by testing TLR-4/6 mRNAs in the human monocyte cell line [149]. They found that all studied NPs activated TLR-6 expression, while AlOOH enhanced both TLR-4 and -6 expression.

Moreover, in human peripheral blood mononuclear cells, the administration of AuNPs activates immune-related genes depends on its physicochemical properties [150]. Lee et al. reported that gold nanorods (GNRs) and $\mathrm{SiO}_{2}$-coated GNRs has a tendency to penetrate into macrophages to induce the release of inflammatory mediators (calcium $(\mathrm{Ca})$, hydrogen peroxide, nitric oxide (NO), cytokines, prostaglandins, etc.) and the activation of immune response genes [151]. Both GNRs and $\mathrm{SiO}_{2}$-coated GNRs have an immunostimulatory property to reinforce immune reactions via calcium-transcription factors pathway.

Fallarini et al. synthesized mono- and disaccharides coated AuNPs with a particle size of $\sim 2$ and $5 \mathrm{~nm}$ [152]. Their in vitro results showed that synthesized NPs initiate the immune response by activating the macrophages. However, unlike monosaccharide coated AuNPs, disaccharide coated tends to induce T cell proliferation and an increase in IL-2 levels. According to this report, the immunoactivity is strongly dependent on size, $5 \mathrm{~nm}$ AuNPs perform far better than $2 \mathrm{~nm}$ ones.

Lin et al. also reported that CPG modified AuNP induced macrophage and DC tumor infiltration and suppresses tumor growth compared with free CpG [153]. Similarly, Ahn et al. also reported that AuNP facilitates tumor-associated self-antigen delivery to DC and then activates the cells to facilitate cross-presentation and induce antigen-specific cytotoxic $T$ cell responses [154].

AgNPs also trigger inflammatory reactions cascade involving the activation of macrophages, neutrophils, and helper T cells [155]. Subsequently, AgNPs enhance the expression of numerous types of cytokines $[156,157]$. Furthermore, different researchers have been investigated the effect of AgNPs as the immunological adjuvant using both in vitro and in vivo studies $[158,159]$.

$\mathrm{Xu}$ et al. have investigated an adjuvant effect of AgNPs [160]. The in vivo result showed that serum antigen-specific IgG and IgE levels were increased, showing that AgNPs elicited CD4 ${ }^{+}$-mediated 
immune response. After 48h treatment with AgNPs, both the number of leukocytes and levels of cytokines TNF- $\alpha$ and IFN- $\gamma$ was increased in abdominal lavage fluid of mice. Furthermore, the expression of the MHC complex class II molecule on the surface of peritoneal macrophages was significantly increased.

In addition, NPs can be designed as artificial APCs (aAPCs), that express surface features, that can activate immune cells or modulate the expression of pro- or anti-inflammatory genes [161,162]. This immunomodulatory behavior of NPs can enhance the therapeutic response of injected NPs by directly generating cytotoxic $\mathrm{T}$ cells. For example, Mandal et al. designed biocompatible and less-toxic anti-CD3 antibodies-modified artificial APCs based on poly (isocyano peptide) [163]. They found that synthesized aAPCs induce a more robust $\mathrm{T}$ cell response in comparison to free antibodies or PLGA particles. Similarly, Kosmides et al. designed and investigated the synergy between a PLGA-based aAPC and an aPD1 mAb [164]. Their in vitro results revealed that the combination of antigen-specific aAPC and aPD1 $\mathrm{mAb}$ induced IFN- $\gamma$ secretion by $\mathrm{CD}^{+} \mathrm{T}$ cells. In addition, in vivo results showed that combination treatment synergistically inhibits tumor growth, while either treatment alone had no effect.

\section{Clinical Translation of Nano-Immunotherapy}

In the last few decades, several researchers have deeply explored a regulatory mechanism of antitumor immunity, particularly the immune checkpoint pathways, which lays a basic foundation for the invention of ICIs, that have revolutionized cancer treatment $[165,166]$. However, different literature showed that the activity of ICIs as monotherapy is not satisfactory for all cancer patients [167]. To address this clinical challenge, the different researchers tried to combine NPs with immunotherapeutic agents or conventional cancer treatment with ICIs $[168,169]$. Several kind of the literature showed that, conventional cancer treatments such as chemotherapy, photodynamic therapy, and radiotherapy can initiate the immune system to elicit a specific antitumor immunity, due to its ability to induce immunogenic cell death, in addition, to directly killing cancer cells, which can induce a release of certain damage-associated molecular patterns (DAMPs) that can activate APCs [170]. Activated APCs in turn phagocytose dying tumor cells and present tumor antigens to initiate T cell responses [171]. By taking this into consideration, NPs-based chemotherapeutic agents or photosensitizer delivery can be used to exploit the ICD inducing properties to achieve potent antitumor efficacy in combination with immunotherapeutic agents such as ICIs [172]. Most importantly, NPs based drug delivery can enhance selective target delivery and reduce off-target cytotoxicity of chemotherapeutic or immunotherapeutic agents which in turn extends the therapeutic index, especially for combination therapy.

As briefly discussed above, targeting APCs, cancer cells or TME clearly indicates that NPs significantly improved the therapeutic efficacy of immunotherapeutic agents. Based on the progress made so far, nano-immunotherapy has been achieving remarkable results, some of them were approved by the FDA, and the majority of them are in the preclinical stage, for the treatment of cancer. The first nano-immunotherapy approved for the treatment of advanced triple-negative breast cancer (TNBC) was Atezolizumab (Tecentriq ${ }^{\circledR}$ ), an ICI against PD-L1, in combination with albumin-bound paclitaxel NP (nab-paclitaxel) $[173,174]$. The result showed that atezolizumab plus nab-paclitaxel significantly prolonged progression-free survival (PFS) compared to nab-paclitaxel in the intent-to-treat population and the PD-L1 positive subgroup.

Furthermore, Hensify ${ }^{\circledR} / \mathrm{NBTXR} 3,50 \mathrm{~nm}$ crystalline hafnium oxide $\left(\mathrm{HfO}_{2}\right) \mathrm{NP}$, received European market approval (CE Mark) in April 2019 for the treatment of locally advanced soft tissue sarcoma in combination with radiation therapy [175]. Hensify ${ }^{\circledR}$ is designed by Nanobiotix to physically destroy tumors and stimulate the immune system locally [176]. Nanobiotix is also running several clinical trials and has received US FDA approval to launch a combination trial with NBTXR3 and PD-1 antibodies to treat lung cancer (NCT03589339).

Similarly, the multicentre, randomized, open-label, phase 3 trial study was conducted as a first-line treatment for metastatic non-squamous non-small-cell lung cancer (IMpower130, NCT02367781) using 
Atezolizumab in combination with carboplatin plus nab-paclitaxel chemotherapy compared with chemotherapy alone [177]. The result revealed that there were significant improvements in median overall survival (OS), 18.6 months in the atezolizumab plus chemotherapy group, 13.9 months in the chemotherapy group, median PFS 7.0 months in the atezolizumab plus chemotherapy group, and 5.5 months in the chemotherapy group.

Furthermore, there is the first randomized phase 3 JAVELIN Ovarian 200 trial (NCT02580058) study which is designed to demonstrate that Avelumab (human immunoglobulin G1 anti-PD-L1 monoclonal antibody) alone or in combination with Pegylated liposomal doxorubicin (PLD) is superior to PLD alone in prolonging OS in patients with platinum-resistant/platinum refractory ovarian cancer [178]. The results revealed that PLD combined with avelumab slightly improved OS (15.7), PFS (3.7), and objective response rate (ORR) (13.3) compared to either PLD (13.1, 3.5, and 4.2 for OS, PFS, and ORR, respectively) or avelumab (11.8, 1.9, and 3.7 for OS, PFS, and ORR, respectively) alone (Reference: ClinicalTrials.gov; NCT0258005). In addition, RNA formulated NPs alone or in combination with immunotherapeutic agents, such as ICIs, were also explored and the majority of them are under clinical trials as listed in Table 1. Moreover, in his recent review, Yang Shi was briefly reviewed several studies that are FDA approved or under clinical trials using nano-immunotherapy, such as NPs albumin-bound paclitaxel, Pegylated liposomal doxorubicin, mRNA nanovaccines, and WDVAX [179].

Table 1. FDA approved nano-Immunotherapy and studies under clinical trials to treat cancer [180-182].

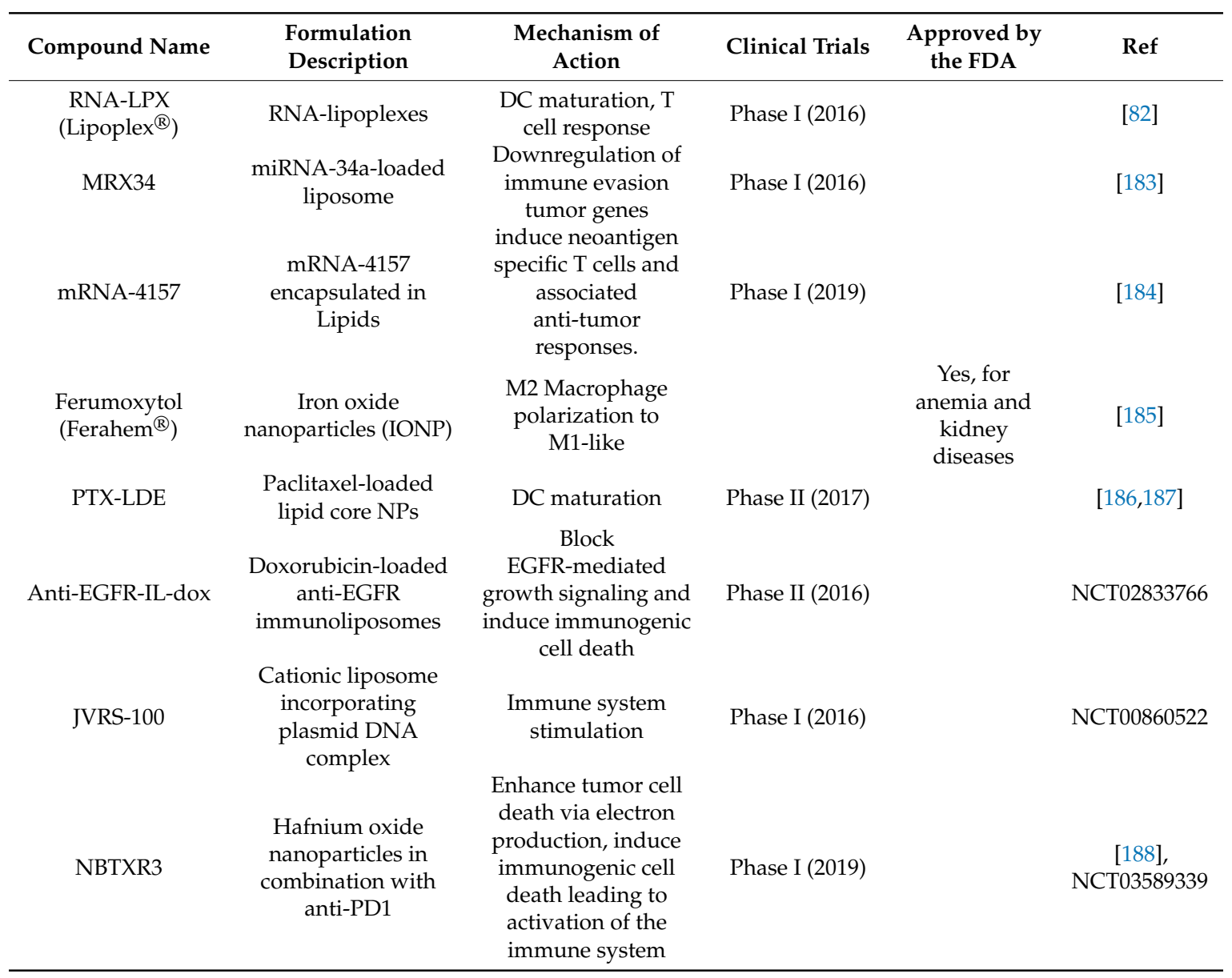

In summary, several clinical and preclinical study results demonstrate that NPs are highly important in immunotherapy as the delivery of immunotherapeutic agents or as the direct immunomodulators. However, due to the multifactorial nature of cancer-immune interactions, identifying unique biomarkers are crucial to designing multifunctional NPs (i.e., which have a diagnostic and theranostic application). Hence, in order to design a novel biomarker-guided multifunctional and 
biocompatible NPs to enhance the efficacy and to promote clinical translation of nano-immunotherapy, a unique biomarker must be identified to distinguish which immune-activating or immunosuppressive cells or pathways are targeted.

\section{Conclusions}

Cancer immunotherapy is emerging as a beneficial tool for cancer treatment by activating the immune system to produce antitumor effects. However, there are some limitations to immunotherapy including poor therapeutic targeting and unwanted side effects. Currently, one of the emerging tracks in this field area is NPs-based immunotherapy which has a considerable potential to solve limitations related to immunotherapy. NPs plays a great role in cancer immunotherapy as the carrier of immunotherapeutic agents and as the direct immunomodulator. NPs based delivery of immunotherapeutic agents offers a great opportunity to minimize unwanted cytotoxicity through controlled release, dose-sparing, or enhanced tumor targeting capabilities. Hence, in the near future, as our knowledge enhanced to understand the detailed molecular mechanism of NPs-immune interaction, NP-based therapies will revolutionize and place NP-based immunotherapy at the forefront of immune-modulating therapeutics.

Author Contributions: T.A.D., conceived, designed, wrote and edited the review paper; C.-F.Y., funding and edited revised manuscript, W.-P.S., supervise, funding and edited the review paper. All authors have read and agreed to the published version of the manuscript.

Funding: This research was funded by the Ministry of Science and Technology, Taiwan; grants number: MOST- 110-2811-B-006-501, 108-2811-B-006-501, 108-2811-B-006-525, 109-2314-B-006-078, 109-2314-B-006-084-MY3, CMNCKU10806 \& Headquarters of University Advancement, National Cheng Kung University, grant number: HUA 109-25-18-133.

Conflicts of Interest: The authors declare no conflict of interest.

\section{References}

1. McCormack, V.A.; Boffetta, P. Today's lifestyles, tomorrow's cancers: Trends in lifestyle risk factors for cancer in low- and middle-income countries. Ann. Oncol. 2011, 22, 2349-2357. [CrossRef] [PubMed]

2. Blackadar, C.B. Historical review of the causes of cancer. World J. Clin. Oncol. 2016, 7, 54-86. [CrossRef] [PubMed]

3. Bray, F.; Ferlay, J.; Soerjomataram, I.; Siegel, R.L.; Torre, L.A.; Jemal, A. Global cancer statistics 2018: GLOBOCAN estimates of incidence and mortality worldwide for 36 cancers in 185 countries. CA Cancer J. Clin. 2018, 68, 394-424. [CrossRef] [PubMed]

4. Arruebo, M.; Vilaboa, N.; Sáez-Gutierrez, B.; Lambea, J.; Tres, A.; Valladares, M.; González-Fernández, A. Assessment of the evolution of cancer treatment therapies. Cancers 2011, 3, 3279-3330. [CrossRef]

5. Suo, X.; Zhang, J.; Zhang, Y.; Liang, X.J.; Zhang, J.; Liu, D. A nano-based thermotherapy for cancer stem cell-targeted therapy. J. Mater. Chem. B 2020, 8, 3985-4001. [CrossRef]

6. Yin, P.T.; Shah, S.; Pasquale, N.J.; Garbuzenko, O.B.; Minko, T.; Lee, K.B. Stem cell-based gene therapy activated using magnetic hyperthermia to enhance the treatment of cancer. Biomaterials 2016, 81, 46-57. [CrossRef]

7. Spring, B.Q.; Rizvi, I.; Xu, N.; Hasan, T. The role of photodynamic therapy in overcoming cancer drug resistance. Photochem. Photobiol. Sci. 2015, 14, 1476-1491. [CrossRef]

8. Weiss, A.; Bonvin, D.; Berndsen, R.H.; Scherrer, E.; Wong, T.J.; Dyson, P.J.; Griffioen, A.W.; Nowak-Sliwinska, P. Angiostatic treatment prior to chemo- or photodynamic therapy improves anti-tumor efficacy. Sci. Rep. 2015, 5, 8990. [CrossRef]

9. Samant, R.S.; Shevde, L.A. Recent advances in anti-angiogenic therapy of cancer. Oncotarget 2011, 2, $122-134$. [CrossRef]

10. Johnston, S.L. Biologic therapies: What and when? J. Clin. Pathol. 2007, 60, 8-17. [CrossRef]

11. Cairns, R.; Papandreou, I.; Denko, N. Overcoming physiologic barriers to cancer treatment by molecularly targeting the tumor microenvironment. Mol. Cancer Res. 2006, 4, 61-70. [CrossRef] [PubMed] 
12. Debele, T.A.; Mekuria, S.L.; Tsai, H.C. Polysaccharide based nanogels in the drug delivery system: Application as the carrier of pharmaceutical agents. Mater. Sci. Eng. C Mater. Biol. Appl. 2016, 68, 964-981. [CrossRef] [PubMed]

13. Maeda, H. SMANCS and polymer-conjugated macromolecular drugs: Advantages in cancer chemotherapy. Adv. Drug Deliv. Rev. 2001, 46, 169-185. [CrossRef]

14. Leu, A.J.; Berk, D.A.; Lymboussaki, A.; Alitalo, K.; Jain, R.K. Absence of functional lymphatics within a murine sarcoma: A molecular and functional evaluation. Cancer Res. 2000, 60, 4324-4327.

15. Maeda, H. Tumor-Selective Delivery of Macromolecular Drugs via the EPR Effect: Background and Future Prospects. Bioconjugate Chem. 2010, 21, 797-802. [CrossRef]

16. Debele, T.A.; Peng, S.; Tsai, H.-C. Drug Carrier for Photodynamic Cancer Therapy. Int. J. Mol. Sci. 2015, 16, 22094-22136. [CrossRef]

17. Chidambaram, M.; Manavalan, R.; Kathiresan, K. Nanotherapeutics to overcome conventional cancer chemotherapy limitations. J. Pharm. Pharm. Sci. 2011, 14, 67-77. [CrossRef]

18. Nel, A.E.; Mädler, L.; Velegol, D.; Xia, T.; Hoek, E.M.V.; Somasundaran, P.; Klaessig, F.; Castranova, V.; Thompson, M. Understanding biophysicochemical interactions at the nano-bio interface. Nat. Mater. 2009, 8, 543-557. [CrossRef]

19. Behzadi, S.; Serpooshan, V.; Tao, W.; Hamaly, M.A.; Alkawareek, M.Y.; Dreaden, E.C.; Brown, D.; Alkilany, A.M.; Farokhzad, O.C.; Mahmoudi, M. Cellular uptake of nanoparticles: Journey inside the cell. Chem. Soc. Rev. 2017, 46, 4218-4244. [CrossRef]

20. Tenzer, S.; Docter, D.; Rosfa, S.; Wlodarski, A.; Kuharev, J.; Rekik, A.; Knauer, S.K.; Bantz, C.; Nawroth, T.; Bier, C.; et al. Nanoparticle size is a critical physicochemical determinant of the human blood plasma corona: A comprehensive quantitative proteomic analysis. ACS Nano 2011, 5, 7155-7167. [CrossRef]

21. Gao, S.; Yang, D.; Fang, Y.; Lin, X.; Jin, X.; Wang, Q.; Wang, X.; Ke, L.; Shi, K. Engineering Nanoparticles for Targeted Remodeling of the Tumor Microenvironment to Improve Cancer Immunotherapy. Theranostics 2019, 9, 126-151. [CrossRef]

22. Fröhlich, E. The role of surface charge in cellular uptake and cytotoxicity of medical nanoparticles. Int. J. Nanomed. 2012, 7, 5577-5591. [CrossRef] [PubMed]

23. He, C.; Hu, Y.; Yin, L.; Tang, C.; Yin, C. Effects of particle size and surface charge on cellular uptake and biodistribution of polymeric nanoparticles. Biomaterials 2010, 31, 3657-3666. [CrossRef] [PubMed]

24. Caracciolo, G.; Callipo, L.; De Sanctis, S.C.; Cavaliere, C.; Pozzi, D.; Laganà, A. Surface adsorption of protein corona controls the cell internalization mechanism of DC-Chol-DOPE/DNA lipoplexes in serum. Biochim. Biophys. Acta (BBA) Biomembranes 2010, 1798, 536-543. [CrossRef] [PubMed]

25. Sacchetti, C.; Motamedchaboki, K.; Magrini, A.; Palmieri, G.; Mattei, M.; Bernardini, S.; Rosato, N.; Bottini, N.; Bottini, M. Surface polyethylene glycol conformation influences the protein corona of polyethylene glycol-modified single-walled carbon nanotubes: Potential implications on biological performance. ACS Nano 2013, 7, 1974-1989. [CrossRef]

26. Pelaz, B.; del Pino, P.; Maffre, P.; Hartmann, R.; Gallego, M.; Rivera-Fernández, S.; de la Fuente, J.M.; Nienhaus, G.U.; Parak, W.J. Surface Functionalization of Nanoparticles with Polyethylene Glycol: Effects on Protein Adsorption and Cellular Uptake. ACS Nano 2015, 9, 6996-7008. [CrossRef]

27. Moore, A.; Marecos, E.; Bogdanov, A., Jr.; Weissleder, R. Tumoral distribution of long-circulating dextran-coated iron oxide nanoparticles in a rodent model. Radiology 2000, 214, 568-574. [CrossRef]

28. Ventola, C.L. Progress in Nanomedicine: Approved and Investigational Nanodrugs. Pharm. Ther. 2017, $42,742-755$.

29. Bobo, D.; Robinson, K.J.; Islam, J.; Thurecht, K.J.; Corrie, S.R. Nanoparticle-Based Medicines: A Review of FDA-Approved Materials and Clinical Trials to Date. Pharm. Res. 2016, 33, 2373-2387. [CrossRef]

30. Etheridge, M.L.; Campbell, S.A.; Erdman, A.G.; Haynes, C.L.; Wolf, S.M.; McCullough, J. The big picture on nanomedicine: The state of investigational and approved nanomedicine products. Nanomedicine 2013, 9, 1-14. [CrossRef]

31. Wang, Y.-X.J. Superparamagnetic iron oxide based MRI contrast agents: Current status of clinical application. Quant. Imaging Med. Surg. 2011, 1, 35-40. [CrossRef]

32. Kendall, M.; Lynch, I. Long-term monitoring for nanomedicine implants and drugs. Nat. Nanotechnol. 2016, 11, 206-210. [CrossRef] [PubMed] 
33. Scott, A.M.; Wolchok, J.D.; Old, L.J. Antibody therapy of cancer. Nat. Rev. Cancer 2012, 12, 278-287. [CrossRef] [PubMed]

34. Havel, J.J.; Chowell, D.; Chan, T.A. The evolving landscape of biomarkers for checkpoint inhibitor immunotherapy. Nat. Rev. Cancer 2019, 19, 133-150. [CrossRef]

35. Dine, J.; Gordon, R.; Shames, Y.; Kasler, M.K.; Barton-Burke, M. Immune Checkpoint Inhibitors: An Innovation in Immunotherapy for the Treatment and Management of Patients with Cancer. Asia Pac. J. Oncol. Nurs. 2017, 4, 127-135. [CrossRef] [PubMed]

36. Sheng, W.Y.; Huang, L. Cancer immunotherapy and nanomedicine. Pharm. Res. 2011, 28, 200-214. [CrossRef] [PubMed]

37. Kim, J.; Gambhir, V.; Alatery, A.; Basta, S. Delivery of Exogenous Antigens to Induce Cytotoxic CD8+ T Lymphocyte Responses. J. Biomed. Biotechnol. 2010, 2010, 218752. [CrossRef]

38. Shresta, S.; Pham, C.T.; Thomas, D.A.; Graubert, T.A.; Ley, T.J. How do cytotoxic lymphocytes kill their targets? Curr. Opin. Immunol. 1998, 10, 581-587. [CrossRef]

39. Basta, S.; Alatery, A. The Cross-priming Pathway: A Portrait of an Intricate Immune System. Scand. J. Immunol. 2007, 65, 311-319. [CrossRef]

40. Bhat, P.; Leggatt, G.; Waterhouse, N.; Frazer, I.H. Interferon- $\gamma$ derived from cytotoxic lymphocytes directly enhances their motility and cytotoxicity. Cell Death Dis. 2017, 8, e2836. [CrossRef]

41. Brinkmann, U.; Kontermann, R.E. The making of bispecific antibodies. $m A$ bs 2017, 9, 182-212. [CrossRef] [PubMed]

42. Frankel, S.R.; Baeuerle, P.A. Targeting T cells to tumor cells using bispecific antibodies. Curr. Opin. Chem. Biol. 2013, 17, 385-392. [CrossRef] [PubMed]

43. Zhang, X.; Yang, Y.; Fan, D.; Xiong, D. The development of bispecific antibodies and their applications in tumor immune escape. Exp. Hematol. Oncol. 2017, 6, 12. [CrossRef] [PubMed]

44. Lindau, D.; Gielen, P.; Kroesen, M.; Wesseling, P.; Adema, G.J. The immunosuppressive tumour network: Myeloid-derived suppressor cells, regulatory T cells and natural killer T cells. Immunology 2013, 138, 105-115. [CrossRef] [PubMed]

45. Hanahan, D.; Weinberg, R.A. Hallmarks of cancer: The next generation. Cell 2011, 144, 646-674. [CrossRef]

46. Fujimura, T.; Kambayashi, Y.; Aiba, S. Crosstalk between regulatory T cells (Tregs) and myeloid derived suppressor cells (MDSCs) during melanoma growth. Oncoimmunology 2012, 1, 1433-1434. [CrossRef]

47. Fujimura, T.; Ring, S.; Umansky, V.; Mahnke, K.; Enk, A.H. Regulatory T cells stimulate B7-H1 expression in myeloid-derived suppressor cells in ret melanomas. J. Investig. Dermatol. 2012, 132, 1239-1246. [CrossRef]

48. Shimizu, J.; Yamazaki, S.; Sakaguchi, S. Induction of tumor immunity by removing CD25+CD4+ T cells: A common basis between tumor immunity and autoimmunity. J. Immunol. 1999, 163, 5211-5218.

49. Onizuka, S.; Tawara, I.; Shimizu, J.; Sakaguchi, S.; Fujita, T.; Nakayama, E. Tumor rejection by in vivo administration of anti-CD25 (interleukin-2 receptor alpha) monoclonal antibody. Cancer Res. 1999, 59, 3128-3133.

50. Yang, L.; Edwards, C.M.; Mundy, G.R. Gr-1+CD11b+ myeloid-derived suppressor cells: Formidable partners in tumor metastasis. J. Bone Miner. Res. 2010, 25, 1701-1706. [CrossRef]

51. Gabrilovich, D.I. Myeloid-Derived Suppressor Cells. Cancer Immunol. Res. 2017, 5, 3-8. [CrossRef]

52. Pucci, C.; Martinelli, C.; Ciofani, G. Innovative approaches for cancer treatment: Current perspectives and new challenges. Ecancermedicalscience 2019, 13, 961. [CrossRef] [PubMed]

53. Urruticoechea, A.; Alemany, R.; Balart, J.; Villanueva, A.; Viñals, F.; Capellá, G. Recent advances in cancer therapy: An overview. Curr. Pharm. Des. 2010, 16, 3-10. [CrossRef] [PubMed]

54. Dimberu, P.M.; Leonhardt, R.M. Cancer immunotherapy takes a multi-faceted approach to kick the immune system into gear. Yale J. Biol. Med. 2011, 84, 371-380. [PubMed]

55. Fang, L.; Lonsdorf, A.S.; Hwang, S.T. Immunotherapy for advanced melanoma. J. Investig. Dermatol. 2008, 128, 2596-2605. [CrossRef] [PubMed]

56. Kaufman, H.L.; Atkins, M.B.; Subedi, P.; Wu, J.; Chambers, J.; Joseph Mattingly, T.; Campbell, J.D.; Allen, J.; Ferris, A.E.; Schilsky, R.L.; et al. The promise of Immuno-oncology: Implications for defining the value of cancer treatment. J. Immunother. Cancer 2019, 7, 129. [CrossRef]

57. Patra, J.K.; Das, G.; Fraceto, L.F.; Campos, E.V.R.; Rodriguez-Torres, M.D.P.; Acosta-Torres, L.S.; Diaz-Torres, L.A.; Grillo, R.; Swamy, M.K.; Sharma, S.; et al. Nano based drug delivery systems: Recent developments and future prospects. J. Nanobiotechnol. 2018, 16, 71. [CrossRef] 
58. Din, F.U.; Aman, W.; Ullah, I.; Qureshi, O.S.; Mustapha, O.; Shafique, S.; Zeb, A. Effective use of nanocarriers as drug delivery systems for the treatment of selected tumors. Int. J. Nanomed. 2017, 12, 7291-7309. [CrossRef]

59. Riley, R.S.; June, C.H.; Langer, R.; Mitchell, M.J. Delivery technologies for cancer immunotherapy. Nat. Rev. Drug Discov. 2019, 18, 175-196. [CrossRef]

60. Schmid, D.; Park, C.G.; Hartl, C.A.; Subedi, N.; Cartwright, A.N.; Puerto, R.B.; Zheng, Y.; Maiarana, J.; Freeman, G.J.; Wucherpfennig, K.W.; et al. T cell-targeting nanoparticles focus delivery of immunotherapy to improve antitumor immunity. Nat. Commun. 2017, 8, 1747. [CrossRef]

61. Mohan, T.; Verma, P.; Rao, D.N. Novel adjuvants \& delivery vehicles for vaccines development: A road ahead. Indian J. Med. Res. 2013, 138, 779-795. [PubMed]

62. Trovato, M.; De Berardinis, P. Novel antigen delivery systems. World J. Virol. 2015, 4, 156-168. [CrossRef] [PubMed]

63. Grippin, A.J.; Sayour, E.J.; Mitchell, D.A. Translational nanoparticle engineering for cancer vaccines. Oncoimmunology 2017, 6, e1290036. [CrossRef] [PubMed]

64. Csaba, N.; Garcia-Fuentes, M.; Alonso, M.J. Nanoparticles for nasal vaccination. Adv. Drug Deliv. Rev. 2009, 61, 140-157. [CrossRef] [PubMed]

65. Hubbell, J.A.; Thomas, S.N.; Swartz, M.A. Materials engineering for immunomodulation. Nature 2009, 462, 449-460. [CrossRef]

66. Zhang, X.-Y.; Lu, W.-Y. Recent advances in lymphatic targeted drug delivery system for tumor metastasis. Cancer Biol. Med. 2014, 11, 247-254. [CrossRef]

67. McLennan, D.N.; Porter, C.J.H.; Charman, S.A. Subcutaneous drug delivery and the role of the lymphatics. Drug Discov. Today Technol. 2005, 2, 89-96. [CrossRef]

68. Moon, J.J.; Huang, B.; Irvine, D.J. Engineering nano- and microparticles to tune immunity. Adv. Mater. 2012, 24, 3724-3746. [CrossRef]

69. Liu, H.; Moynihan, K.D.; Zheng, Y.; Szeto, G.L.; Li, A.V.; Huang, B.; Van Egeren, D.S.; Park, C.; Irvine, D.J. Structure-based programming of lymph-node targeting in molecular vaccines. Nature 2014, 507, 519-522. [CrossRef]

70. Oussoren, C.; Storm, G. Liposomes to target the lymphatics by subcutaneous administration. Adv. Drug Deliv. Rev. 2001, 50, 143-156. [CrossRef]

71. Reddy, S.T.; van der Vlies, A.J.; Simeoni, E.; Angeli, V.; Randolph, G.J.; O'Neil, C.P.; Lee, L.K.; Swartz, M.A.; Hubbell, J.A. Exploiting lymphatic transport and complement activation in nanoparticle vaccines. Nat. Biotechnol. 2007, 25, 1159-1164. [CrossRef] [PubMed]

72. Fifis, T.; Gamvrellis, A.; Crimeen-Irwin, B.; Pietersz, G.A.; Li, J.; Mottram, P.L.; McKenzie, I.F.; Plebanski, M. Size-dependent immunogenicity: Therapeutic and protective properties of nano-vaccines against tumors. J. Immunol. 2004, 173, 3148-3154. [CrossRef]

73. Irvine, D.J.; Hanson, M.C.; Rakhra, K.; Tokatlian, T. Synthetic Nanoparticles for Vaccines and Immunotherapy. Chem. Rev. 2015, 115, 11109-11146. [CrossRef] [PubMed]

74. Kourtis, I.C.; Hirosue, S.; de Titta, A.; Kontos, S.; Stegmann, T.; Hubbell, J.A.; Swartz, M.A. Peripherally administered nanoparticles target monocytic myeloid cells, secondary lymphoid organs and tumors in mice. PLoS ONE 2013, 8, e61646. [CrossRef]

75. Mueller, S.N.; Tian, S.; DeSimone, J.M. Rapid and Persistent Delivery of Antigen by Lymph Node Targeting PRINT Nanoparticle Vaccine Carrier To Promote Humoral Immunity. Mol. Pharm. 2015, 12, 1356-1365. [CrossRef]

76. Zhan, X.; Tran, K.K.; Shen, H. Effect of the Poly(ethylene glycol) (PEG) Density on the Access and Uptake of Particles by Antigen-Presenting Cells (APCs) after Subcutaneous Administration. Mol. Pharm. 2012, 9, 3442-3451. [CrossRef]

77. Song, W.; Shen, L.; Wang, Y.; Liu, Q.; Goodwin, T.J.; Li, J.; Dorosheva, O.; Liu, T.; Liu, R.; Huang, L. Synergistic and low adverse effect cancer immunotherapy by immunogenic chemotherapy and locally expressed PD-L1 trap. Nat. Commun. 2018, 9, 2237. [CrossRef] [PubMed]

78. Gaudino, S.J.; Kumar, P. Cross-Talk Between Antigen Presenting Cells and T Cells Impacts Intestinal Homeostasis, Bacterial Infections, and Tumorigenesis. Front. Immunol. 2019, 10. [CrossRef] [PubMed]

79. Burgdorf, S.; Kautz, A.; Böhnert, V.; Knolle, P.A.; Kurts, C. Distinct pathways of antigen uptake and intracellular routing in CD4 and CD8 T cell activation. Science 2007, 316, 612-616. [CrossRef] [PubMed] 
80. Swartz, M.A.; Hirosue, S.; Hubbell, J.A. Engineering approaches to immunotherapy. Sci. Transl. Med. 2012, 4, 148rv9. [CrossRef]

81. Shen, H.; Ackerman, A.L.; Cody, V.; Giodini, A.; Hinson, E.R.; Cresswell, P.; Edelson, R.L.; Saltzman, W.M.; Hanlon, D.J. Enhanced and prolonged cross-presentation following endosomal escape of exogenous antigens encapsulated in biodegradable nanoparticles. Immunology 2006, 117, 78-88. [CrossRef] [PubMed]

82. Kranz, L.M.; Diken, M.; Haas, H.; Kreiter, S.; Loquai, C.; Reuter, K.C.; Meng, M.; Fritz, D.; Vascotto, F.; Hefesha, H.; et al. Systemic RNA delivery to dendritic cells exploits antiviral defence for cancer immunotherapy. Nature 2016, 534, 396-401. [CrossRef] [PubMed]

83. Wille-Reece, U.; Flynn, B.J.; Loré, K.; Koup, R.A.; Kedl, R.M.; Mattapallil, J.J.; Weiss, W.R.; Roederer, M.; Seder, R.A. HIV Gag protein conjugated to a Toll-like receptor 7/8 agonist improves the magnitude and quality of Th1 and CD8 ${ }^{+}$T cell responses in nonhuman primates. Proc. Natl. Acad. Sci. USA 2005, 102, 15190. [CrossRef] [PubMed]

84. Bandyopadhyay, A.; Fine, R.L.; Demento, S.; Bockenstedt, L.K.; Fahmy, T.M. The impact of nanoparticle ligand density on dendritic-cell targeted vaccines. Biomaterials 2011, 32, 3094-3105. [CrossRef]

85. Bonifaz, L.C.; Bonnyay, D.P.; Charalambous, A.; Darguste, D.I.; Fujii, S.; Soares, H.; Brimnes, M.K.; Moltedo, B.; Moran, T.M.; Steinman, R.M. In vivo targeting of antigens to maturing dendritic cells via the DEC-205 receptor improves T cell vaccination. J. Exp. Med. 2004, 199, 815-824. [CrossRef]

86. Bozzacco, L.; Trumpfheller, C.; Siegal, F.P.; Mehandru, S.; Markowitz, M.; Carrington, M.; Nussenzweig, M.C.; Piperno, A.G.; Steinman, R.M. DEC-205 receptor on dendritic cells mediates presentation of HIV gag protein to $\mathrm{CD}^{+} \mathrm{T}$ cells in a spectrum of human MHC I haplotypes. Proc. Natl. Acad. Sci. USA 2007, 104, 1289. [CrossRef]

87. Cruz, L.J.; Rosalia, R.A.; Kleinovink, J.W.; Rueda, F.; Löwik, C.W.G.M.; Ossendorp, F. Targeting nanoparticles to CD40, DEC-205 or CD11c molecules on dendritic cells for efficient CD8+ T cell response: A comparative study. J. Control. Release 2014, 192, 209-218. [CrossRef]

88. Schlosser, E.; Mueller, M.; Fischer, S.; Basta, S.; Busch, D.H.; Gander, B.; Groettrup, M. TLR ligands and antigen need to be coencapsulated into the same biodegradable microsphere for the generation of potent cytotoxic T lymphocyte responses. Vaccine 2008, 26, 1626-1637. [CrossRef]

89. Chiang, C.L.; Kandalaft, L.E.; Coukos, G. Adjuvants for enhancing the immunogenicity of whole tumor cell vaccines. Int. Rev. Immunol. 2011, 30, 150-182. [CrossRef]

90. Soiffer, R.; Hodi, F.S.; Haluska, F.; Jung, K.; Gillessen, S.; Singer, S.; Tanabe, K.; Duda, R.; Mentzer, S.; Jaklitsch, M.; et al. Vaccination With Irradiated, Autologous Melanoma Cells Engineered to Secrete Granulocyte-Macrophage Colony-Stimulating Factor by Adenoviral-Mediated Gene Transfer Augments Antitumor Immunity in Patients With Metastatic Melanoma. J. Clin. Oncol. 2003, 21, 3343-3350. [CrossRef]

91. Zhu, G.; Zhang, F.; Ni, Q.; Niu, G.; Chen, X. Efficient Nanovaccine Delivery in Cancer Immunotherapy. ACS Nano 2017, 11, 2387-2392. [CrossRef] [PubMed]

92. Kuai, R.; Ochyl, L.J.; Bahjat, K.S.; Schwendeman, A.; Moon, J.J. Designer vaccine nanodiscs for personalized cancer immunotherapy. Nat. Mater. 2017, 16, 489-496. [CrossRef] [PubMed]

93. Liu, S.-Y.; Wei, W.; Yue, H.; Ni, D.-Z.; Yue, Z.-G.; Wang, S.; Fu, Q.; Wang, Y.-Q.; Ma, G.-H.; Su, Z.-G. Nanoparticles-based multi-adjuvant whole cell tumor vaccine for cancer immunotherapy. Biomaterials 2013, 34, 8291-8300. [CrossRef] [PubMed]

94. Balkwill, F.R.; Capasso, M.; Hagemann, T. The tumor microenvironment at a glance. J. Cell Sci. 2012, 125, 5591. [CrossRef]

95. Lechner, M.G.; Liebertz, D.J.; Epstein, A.L. Characterization of cytokine-induced myeloid-derived suppressor cells from normal human peripheral blood mononuclear cells. J. Immunol. 2010, 185, 2273-2284. [CrossRef]

96. Jayaraman, P.; Parikh, F.; Lopez-Rivera, E.; Hailemichael, Y.; Clark, A.; Ma, G.; Cannan, D.; Ramacher, M.; Kato, M.; Overwijk, W.W.; et al. Tumor-expressed inducible nitric oxide synthase controls induction of functional myeloid-derived suppressor cells through modulation of vascular endothelial growth factor release. J. Immunol. 2012, 188, 5365-5376. [CrossRef]

97. Mandapathil, M.; Szczepanski, M.J.; Szajnik, M.; Ren, J.; Jackson, E.K.; Johnson, J.T.; Gorelik, E.; Lang, S.; Whiteside, T.L. Adenosine and prostaglandin E2 cooperate in the suppression of immune responses mediated by adaptive regulatory T cells. J. Biol. Chem. 2010, 285, 27571-27580. [CrossRef]

98. Rodríguez, P.C.; Ochoa, A.C. Arginine regulation by myeloid derived suppressor cells and tolerance in cancer: Mechanisms and therapeutic perspectives. Immunol. Rev. 2008, 222, 180-191. [CrossRef] 
99. Godin-Ethier, J.; Hanafi, L.A.; Piccirillo, C.A.; Lapointe, R. Indoleamine 2,3-dioxygenase expression in human cancers: Clinical and immunologic perspectives. Clin. Cancer Res. 2011, 17, 6985-6991. [CrossRef]

100. Platten, M.; Wick, W.; Van den Eynde, B.J. Tryptophan catabolism in cancer: Beyond IDO and tryptophan depletion. Cancer Res. 2012, 72, 5435-5440. [CrossRef]

101. De la Fuente, H.; Cibrián, D.; Sánchez-Madrid, F. Immunoregulatory molecules are master regulators of inflammation during the immune response. FEBS Lett. 2012, 586, 2897-2905. [CrossRef] [PubMed]

102. Su, T.; Yang, B.; Gao, T.; Liu, T.; Li, J. Polymer nanoparticle-assisted chemotherapy of pancreatic cancer. Ther. Adv. Med. Oncol. 2020, 12. [CrossRef] [PubMed]

103. Whiteside, T.L. The tumor microenvironment and its role in promoting tumor growth. Oncogene 2008, 27, 5904-5912. [CrossRef] [PubMed]

104. Estrella, V.; Chen, T.; Lloyd, M.; Wojtkowiak, J.; Cornnell, H.H.; Ibrahim-Hashim, A.; Bailey, K.; Balagurunathan, Y.; Rothberg, J.M.; Sloane, B.F.; et al. Acidity generated by the tumor microenvironment drives local invasion. Cancer Res. 2013, 73, 1524-1535. [CrossRef] [PubMed]

105. Sacchetti, C.; Rapini, N.; Magrini, A.; Cirelli, E.; Bellucci, S.; Mattei, M.; Rosato, N.; Bottini, N.; Bottini, M. In Vivo Targeting of Intratumor Regulatory T Cells Using PEG-Modified Single-Walled Carbon Nanotubes. Bioconjugate Chem. 2013, 24, 852-858. [CrossRef] [PubMed]

106. Zhu, S.; Niu, M.; O’Mary, H.; Cui, Z. Targeting of tumor-associated macrophages made possible by PEG-sheddable, mannose-modified nanoparticles. Mol. Pharm. 2013, 10, 3525-3530. [CrossRef] [PubMed]

107. Park, J.; Wrzesinski, S.H.; Stern, E.; Look, M.; Criscione, J.; Ragheb, R.; Jay, S.M.; Demento, S.L.; Agawu, A.; Licona Limon, P.; et al. Combination delivery of TGF- $\beta$ inhibitor and IL-2 by nanoscale liposomal polymeric gels enhances tumour immunotherapy. Nat. Mater. 2012, 11, 895-905. [CrossRef] [PubMed]

108. Wei, S.C.; Duffy, C.R.; Allison, J.P. Fundamental Mechanisms of Immune Checkpoint Blockade Therapy. Cancer Discov. 2018, 8, 1069. [CrossRef]

109. Riva, A.; Chokshi, S. Immune checkpoint receptors: Homeostatic regulators of immunity. Hepatol. Int. 2018, 12, 223-236. [CrossRef]

110. Sharpe, A.H.; Wherry, E.J.; Ahmed, R.; Freeman, G.J. The function of programmed cell death 1 and its ligands in regulating autoimmunity and infection. Nat. Immunol. 2007, 8, 239-245. [CrossRef]

111. Nirschl, C.J.; Drake, C.G. Molecular pathways: Coexpression of immune checkpoint molecules: Signaling pathways and implications for cancer immunotherapy. Clin. Cancer Res. 2013, 19, 4917-4924. [CrossRef] [PubMed]

112. Zappasodi, R.; Merghoub, T.; Wolchok, J.D. Emerging Concepts for Immune Checkpoint Blockade-Based Combination Therapies. Cancer Cell 2018, 33, 581-598. [CrossRef] [PubMed]

113. Marin-Acevedo, J.A.; Dholaria, B.; Soyano, A.E.; Knutson, K.L.; Chumsri, S.; Lou, Y. Next generation of immune checkpoint therapy in cancer: New developments and challenges. J. Hematol. Oncol. 2018, 11, 39. [CrossRef] [PubMed]

114. Pardoll, D.M. The blockade of immune checkpoints in cancer immunotherapy. Nat. Rev. Cancer 2012, 12, 252-264. [CrossRef] [PubMed]

115. Altmann, D.M. A Nobel Prize-worthy pursuit: Cancer immunology and harnessing immunity to tumour neoantigens. Immunology 2018, 155, 283-284. [CrossRef] [PubMed]

116. Sharma, P.; Allison, J.P. The future of immune checkpoint therapy. Science 2015, 348, 56. [CrossRef]

117. Topalian, S.L.; Drake, C.G.; Pardoll, D.M. Immune checkpoint blockade: A common denominator approach to cancer therapy. Cancer Cell 2015, 27, 450-461. [CrossRef]

118. Leach, D.R.; Krummel, M.F.; Allison, J.P. Enhancement of antitumor immunity by CTLA-4 blockade. Science 1996, 271, 1734-1736. [CrossRef]

119. Chen, L. Co-inhibitory molecules of the B7-CD28 family in the control of T-cell immunity. Nat. Rev. Immunol. 2004, 4, 336-347. [CrossRef]

120. Keir, M.E.; Butte, M.J.; Freeman, G.J.; Sharpe, A.H. PD-1 and its ligands in tolerance and immunity. Annu. Rev. Immunol. 2008, 26, 677-704. [CrossRef]

121. Hodi, F.S.; O’Day, S.J.; McDermott, D.F.; Weber, R.W.; Sosman, J.A.; Haanen, J.B.; Gonzalez, R.; Robert, C.; Schadendorf, D.; Hassel, J.C.; et al. Improved Survival with Ipilimumab in Patients with Metastatic Melanoma. N. Engl. J. Med. 2010, 363, 711-723. [CrossRef] [PubMed] 
122. Topalian, S.L.; Hodi, F.S.; Brahmer, J.R.; Gettinger, S.N.; Smith, D.C.; McDermott, D.F.; Powderly, J.D.; Carvajal, R.D.; Sosman, J.A.; Atkins, M.B.; et al. Safety, activity, and immune correlates of anti-PD-1 antibody in cancer. N. Engl. J. Med. 2012, 366, 2443-2454. [CrossRef] [PubMed]

123. Shih, K.; Arkenau, H.-T.; Infante, J.R. Clinical impact of checkpoint inhibitors as novel cancer therapies. Drugs 2014, 74, 1993-2013. [CrossRef] [PubMed]

124. Hui, E. Immune checkpoint inhibitors. J. Cell Biol. 2019, 218, 740-741. [CrossRef] [PubMed]

125. Vaddepally, R.K.; Kharel, P.; Pandey, R.; Garje, R.; Chandra, A.B. Review of Indications of FDA-Approved Immune Checkpoint Inhibitors per NCCN Guidelines with the Level of Evidence. Cancers 2020, 12, 738. [CrossRef] [PubMed]

126. Wang, C.; Ye, Y.; Hochu, G.M.; Sadeghifar, H.; Gu, Z. Enhanced Cancer Immunotherapy by Microneedle Patch-Assisted Delivery of Anti-PD1 Antibody. Nano Lett. 2016, 16, 2334-2340. [CrossRef]

127. Wang, C.; Sun, W.; Wright, G.; Wang, A.Z.; Gu, Z. Inflammation-Triggered Cancer Immunotherapy by Programmed Delivery of CpG and Anti-PD1 Antibody. Adv. Mater. 2017, 29. [CrossRef]

128. Zou, W.; Wolchok, J.D.; Chen, L. PD-L1 (B7-H1) and PD-1 pathway blockade for cancer therapy: Mechanisms, response biomarkers, and combinations. Sci. Transl. Med. 2016, 8, 283-291. [CrossRef]

129. Bai, R.; Chen, N.; Li, L.; Du, N.; Bai, L.; Lv, Z.; Tian, H.; Cui, J. Mechanisms of Cancer Resistance to Immunotherapy. Front. Oncol. 2020, 10, 1290. [CrossRef]

130. Feinberg, A.P.; Koldobskiy, M.A.; Göndör, A. Epigenetic modulators, modifiers and mediators in cancer aetiology and progression. Nat. Rev. Genet. 2016, 17, 284-299. [CrossRef]

131. Héninger, E.; Krueger, T.E.G.; Lang, J.M. Augmenting antitumor immune responses with epigenetic modifying agents. Front. Immunol. 2015, 6, 29. [CrossRef] [PubMed]

132. Ruan, H.; Hu, Q.; Wen, D.; Chen, Q.; Chen, G.; Lu, Y.; Wang, J.; Cheng, H.; Lu, W.; Gu, Z. A Dual-Bioresponsive Drug-Delivery Depot for Combination of Epigenetic Modulation and Immune Checkpoint Blockade. Adv. Mater. 2019, 31, e1806957. [CrossRef] [PubMed]

133. Min, Y.; Roche, K.C.; Tian, S.; Eblan, M.J.; McKinnon, K.P.; Caster, J.M.; Chai, S.; Herring, L.E.; Zhang, L.; Zhang, T; et al. Antigen-capturing nanoparticles improve the abscopal effect and cancer immunotherapy. Nat. Nanotechnol. 2017, 12, 877-882. [CrossRef] [PubMed]

134. Palena, C.; Abrams, S.I.; Schlom, J.; Hodge, J.W. Cancer vaccines: Preclinical studies and novel strategies. Adv. Cancer Res. 2006, 95, 115-145. [CrossRef] [PubMed]

135. Ogi, C.; Aruga, A. Immunological monitoring of anticancer vaccines in clinical trials. Oncoimmunology 2013, 2, e26012. [CrossRef]

136. Kim, Y.; Kang, S.; Shin, H.; Kim, T.; Yu, B.; Kim, J.; Yoo, D.; Jon, S. Sequential and Timely Combination of a Cancer Nanovaccine with Immune Checkpoint Blockade Effectively Inhibits Tumor Growth and Relapse. Angew. Chem. Int. Ed. 2020, 59, 14628-14638. [CrossRef]

137. Fontana, F.; Fusciello, M.; Groeneveldt, C.; Capasso, C.; Chiaro, J.; Feola, S.; Liu, Z.; Mäkilä, E.M.; Salonen, J.J.; Hirvonen, J.T.; et al. Biohybrid Vaccines for Improved Treatment of Aggressive Melanoma with Checkpoint Inhibitor. ACS Nano 2019, 13, 6477-6490. [CrossRef]

138. Zhuang, J.; Holay, M.; Park, J.H.; Fang, R.H.; Zhang, J.; Zhang, L. Nanoparticle Delivery of Immunostimulatory Agents for Cancer Immunotherapy. Theranostics 2019, 9, 7826-7848. [CrossRef]

139. Sushnitha, M.; Evangelopoulos, M.; Tasciotti, E.; Taraballi, F. Cell Membrane-Based Biomimetic Nanoparticles and the Immune System: Immunomodulatory Interactions to Therapeutic Applications. Front. Bioeng. Biotechnol. 2020, 8. [CrossRef]

140. Getts, D.R.; Shea, L.D.; Miller, S.D.; King, N.J. Harnessing nanoparticles for immune modulation. Trends Iimmunol. 2015, 36, 419-427. [CrossRef]

141. Jiao, Q.; Li, L.; Mu, Q.; Zhang, Q. Immunomodulation of nanoparticles in nanomedicine applications. BioMed Res. Int. 2014, 2014, 426028. [CrossRef] [PubMed]

142. Liu, X.-Q.; Tang, R.-Z. Biological responses to nanomaterials: Understanding nano-bio effects on cell behaviors. Drug Deliv. 2017, 24, 1-15. [CrossRef] [PubMed]

143. Luo, Y.-H.; Chang, L.W.; Lin, P. Metal-Based Nanoparticles and the Immune System: Activation, Inflammation, and Potential Applications. BioMed Res. Int. 2015, 2015, 143720. [CrossRef] [PubMed]

144. Fadeel, B. Hide and Seek: Nanomaterial Interactions with the Immune System. Front. Immunol. 2019, 10, 133. [CrossRef] [PubMed]

145. Akira, S.; Takeda, K. Toll-like receptor signalling. Nat. Rev. Immunol. 2004, 4, 499-511. [CrossRef] [PubMed] 
146. Chugh, H.; Sood, D.; Chandra, I.; Tomar, V.; Dhawan, G.; Chandra, R. Role of gold and silver nanoparticles in cancer nano-medicine. Artif. Cells Nanomed. Biotechnol. 2018, 46, 1210-1220. [CrossRef] [PubMed]

147. Yen, H.J.; Hsu, S.H.; Tsai, C.L. Cytotoxicity and immunological response of gold and silver nanoparticles of different sizes. Small 2009, 5, 1553-1561. [CrossRef]

148. Wolf-Grosse, S.; Mollnes, T.E.; Ali, S.; Stenvik, J.; Nilsen, A.M. Iron oxide nanoparticles enhance Toll-like receptor-induced cytokines in a particle size- and actin-dependent manner in human blood. Nanomedicine 2018, 13, 1773-1785. [CrossRef]

149. Vasilichin, V.A.; Tsymbal, S.A.; Fakhardo, A.F.; Anastasova, E.I.; Marchenko, A.S.; Shtil, A.A.; Vinogradov, V.V.; Koshel, E.I. Effects of Metal Oxide Nanoparticles on Toll-Like Receptor mRNAs in Human Monocytes. Nanomaterials 2020, 10, 127. [CrossRef]

150. Dykman, L.A.; Khlebtsov, N.G. Immunological properties of gold nanoparticles. Chem. Sci. 2017, 8, $1719-1735$. [CrossRef]

151. Lee, J.Y.; Park, W.; Yi, D.K. Immunostimulatory effects of gold nanorod and silica-coated gold nanorod on RAW 264.7 mouse macrophages. Toxicol. Lett. 2012, 209, 51-57. [CrossRef] [PubMed]

152. Fallarini, S.; Paoletti, T.; Battaglini, C.O.; Ronchi, P.; Lay, L.; Bonomi, R.; Jha, S.; Mancin, F.; Scrimin, P.; Lombardi, G. Factors affecting $\mathrm{T}$ cell responses induced by fully synthetic glyco-gold-nanoparticles. Nanoscale 2013, 5, 390-400. [CrossRef] [PubMed]

153. Lin, A.Y.; Mattos Almeida, J.P.; Bear, A.; Liu, N.; Luo, L.; Foster, A.E.; Drezek, R.A. Gold Nanoparticle Delivery of Modified CpG Stimulates Macrophages and Inhibits Tumor Growth for Enhanced Immunotherapy. PLoS ONE 2013, 8, e63550. [CrossRef] [PubMed]

154. Ahn, S.; Lee, I.H.; Kang, S.; Kim, D.; Choi, M.; Saw, P.E.; Shin, E.C.; Jon, S. Gold nanoparticles displaying tumor-associated self-antigens as a potential vaccine for cancer immunotherapy. Adv. Healthc. Mater. 2014, 3, 1194-1199. [CrossRef] [PubMed]

155. Ninan, N.; Goswami, N.; Vasilev, K. The Impact of Engineered Silver Nanomaterials on the Immune System. Nanomaterials 2020, 10, 967. [CrossRef] [PubMed]

156. Elsabahy, M.; Wooley, K.L. Cytokines as biomarkers of nanoparticle immunotoxicity. Chem. Soc. Rev. 2013, 42, 5552-5576. [CrossRef] [PubMed]

157. Carlson, C.; Hussain, S.M.; Schrand, A.M.; Braydich-Stolle, L.K.; Hess, K.L.; Jones, R.L.; Schlager, J.J. Unique cellular interaction of silver nanoparticles: Size-dependent generation of reactive oxygen species. J. Phys. Chem. B 2008, 112, 13608-13619. [CrossRef]

158. Asgary, V.; Shoari, A.; Baghbani-Arani, F.; Sadat Shandiz, S.A.; Khosravy, M.S.; Janani, A.; Bigdeli, R.; Bashar, R.; Cohan, R.A. Green synthesis and evaluation of silver nanoparticles as adjuvant in rabies veterinary vaccine. Int. J. Nanomed. 2016, 11, 3597-3605. [CrossRef]

159. Liu, Y.; Balachandran, Y.L.; Li, D.; Shao, Y.; Jiang, X. Polyvinylpyrrolidone-Poly(ethylene glycol) Modified Silver Nanorods Can Be a Safe, Noncarrier Adjuvant for HIV Vaccine. ACS Nano 2016, 10, 3589-3596. [CrossRef]

160. Xu, Y.; Tang, H.; Liu, J.-H.; Wang, H.; Liu, Y. Evaluation of the adjuvant effect of silver nanoparticles both in vitro and in vivo. Toxicol. Lett. 2013, 219, 42-48. [CrossRef]

161. Kim, J.V.; Latouche, J.-B.; Rivière, I.; Sadelain, M. The ABCs of artificial antigen presentation. Nat. Biotechnol. 2004, 22, 403-410. [CrossRef] [PubMed]

162. Rhodes, K.R.; Green, J.J. Nanoscale artificial antigen presenting cells for cancer immunotherapy. Mol. Immunol. 2018, 98, 13-18. [CrossRef] [PubMed]

163. Mandal, S.; Eksteen-Akeroyd, Z.H.; Jacobs, M.J.; Hammink, R.; Koepf, M.; Lambeck, A.J.A.; van Hest, J.C.M.; Wilson, C.J.; Blank, K.; Figdor, C.G.; et al. Therapeutic nanoworms: Towards novel synthetic dendritic cells for immunotherapy. Chem. Sci. 2013, 4, 4168-4174. [CrossRef]

164. Kosmides, A.K.; Meyer, R.A.; Hickey, J.W.; Aje, K.; Cheung, K.N.; Green, J.J.; Schneck, J.P. Biomimetic biodegradable artificial antigen presenting cells synergize with PD-1 blockade to treat melanoma. Biomaterials 2017, 118, 16-26. [CrossRef] [PubMed]

165. Balar, A.V.; Weber, J.S. PD-1 and PD-L1 antibodies in cancer: Current status and future directions. Cancer Immunol. Immunother. 2017, 66, 551-564. [CrossRef] [PubMed]

166. Li, Y.; Li, F.; Jiang, F.; Lv, X.; Zhang, R.; Lu, A.; Zhang, G. A Mini-Review for Cancer Immunotherapy: Molecular Understanding of PD-1/PD-L1 Pathway \& Translational Blockade of Immune Checkpoints. Int. J. Mol. Sci. 2016, 17, 1151. [CrossRef] 
167. Wang, Q.; Wu, X. Primary and acquired resistance to PD-1/PD-L1 blockade in cancer treatment. Int. Immunopharmacol. 2017, 46, 210-219. [CrossRef]

168. Sun, L.; Zhang, L.; Yu, J.; Zhang, Y.; Pang, X.; Ma, C.; Shen, M.; Ruan, S.; Wasan, H.S.; Qiu, S. Clinical efficacy and safety of anti-PD-1/PD-L1 inhibitors for the treatment of advanced or metastatic cancer: A systematic review and meta-analysis. Sci. Rep. 2020, 10, 2083. [CrossRef]

169. Sui, X.; Ma, J.; Han, W.; Wang, X.; Fang, Y.; Li, D.; Pan, H.; Zhang, L. The anticancer immune response of anti-PD-1/PD-L1 and the genetic determinants of response to anti-PD-1/PD-L1 antibodies in cancer patients. Oncotarget 2015, 6, 19393-19404. [CrossRef]

170. Kroemer, G.; Galluzzi, L.; Kepp, O.; Zitvogel, L. Immunogenic Cell Death in Cancer Therapy. Annu. Rev. Immunol. 2013, 31, 51-72. [CrossRef]

171. Fucikova, J.; Kralikova, P.; Fialova, A.; Brtnicky, T.; Rob, L.; Bartunkova, J.; Spísek, R. Human tumor cells killed by anthracyclines induce a tumor-specific immune response. Cancer Res. 2011, 71, 4821-4833. [CrossRef] [PubMed]

172. Nam, J.; Son, S.; Park, K.S.; Zou, W.; Shea, L.D.; Moon, J.J. Cancer nanomedicine for combination cancer immunotherapy. Nat. Rev. Mater. 2019, 4, 398-414. [CrossRef]

173. Schmid, P.; Adams, S.; Rugo, H.S.; Schneeweiss, A.; Barrios, C.H.; Iwata, H.; Diéras, V.; Hegg, R.; Im, S.-A.; Shaw Wright, G.; et al. Atezolizumab and Nab-Paclitaxel in Advanced Triple-Negative Breast Cancer. N. Engl. J. Med. 2018, 379, 2108-2121. [CrossRef] [PubMed]

174. Kang, C.; Syed, Y.Y. Atezolizumab (in Combination with Nab-Paclitaxel): A Review in Advanced Triple-Negative Breast Cancer. Drugs 2020, 80, 601-607. [CrossRef]

175. Bonvalot, S.; Rutkowski, P.L.; Thariat, J.; Carrère, S.; Ducassou, A.; Sunyach, M.P.; Agoston, P.; Hong, A.; Mervoyer, A.; Rastrelli, M.; et al. NBTXR3, a first-in-class radioenhancer hafnium oxide nanoparticle, plus radiotherapy versus radiotherapy alone in patients with locally advanced soft-tissue sarcoma (Act.In.Sarc): A multicentre, phase 2-3, randomised, controlled trial. Lancet Oncol. 2019, 20, 1148-1159. [CrossRef]

176. Bonvalot, S.; Le Pechoux, C.; De Baere, T.; Kantor, G.; Buy, X.; Stoeckle, E.; Terrier, P.; Sargos, P.; Coindre, J.M.; Lassau, N.; et al. First-in-Human Study Testing a New Radioenhancer Using Nanoparticles (NBTXR3) Activated by Radiation Therapy in Patients with Locally Advanced Soft Tissue Sarcomas. Clin. Cancer Res. 2017, 23, 908-917. [CrossRef]

177. West, H.; McCleod, M.; Hussein, M.; Morabito, A.; Rittmeyer, A.; Conter, H.J.; Kopp, H.G.; Daniel, D.; McCune, S.; Mekhail, T.; et al. Atezolizumab in combination with carboplatin plus nab-paclitaxel chemotherapy compared with chemotherapy alone as first-line treatment for metastatic non-squamous non-small-cell lung cancer (IMpower130): A multicentre, randomised, open-label, phase 3 trial. Lancet Oncol. 2019, 20, 924-937. [CrossRef]

178. Pujade-Lauraine, E.; Fujiwara, K.; Dychter, S.S.; Devgan, G.; Monk, B.J. Avelumab (anti-PD-L1) in platinum-resistant/refractory ovarian cancer: JAVELIN Ovarian 200 Phase III study design. Future Oncol. 2018, 14, 2103-2113. [CrossRef]

179. Shi, Y. Clinical Translation of Nanomedicine and Biomaterials for Cancer Immunotherapy: Progress and Perspectives. Adv. Ther. 2020, 3, 1900215. [CrossRef]

180. Mikelez-Alonso, I.; Aires, A.; Cortajarena, A.L. Cancer Nano-Immunotherapy from the Injection to the Target: The Role of Protein Corona. Int. J. Mol. Sci. 2020, 21, 519. [CrossRef]

181. Yetisgin, A.A.; Cetinel, S.; Zuvin, M.; Kosar, A.; Kutlu, O. Therapeutic Nanoparticles and Their Targeted Delivery Applications. Molecules 2020, 25, 2193. [CrossRef] [PubMed]

182. Anselmo, A.C.; Mitragotri, S. Nanoparticles in the clinic: An update. Bioeng. Transl. Med. 2019, 4, e10143. [CrossRef] [PubMed]

183. Beg, M.S.; Brenner, A.J.; Sachdev, J.; Borad, M.; Kang, Y.K.; Stoudemire, J.; Smith, S.; Bader, A.G.; Kim, S.; Hong, D.S. Phase I study of MRX34, a liposomal miR-34a mimic, administered twice weekly in patients with advanced solid tumors. Investig. New Drugs 2017, 35, 180-188. [CrossRef] [PubMed]

184. Burris, H.A., III; Patel, M.R.; Cho, D.C.; Clarke, J.M.; Gutierrez, M.; Zaks, T.Z.; Frederick, J.; Hopson, K.; Mody, K.; Binanti-Berube, A.; et al. A phase 1, open-label, multicenter study to assess the safety, tolerability, and immunogenicity of mRNA-4157 alone in subjects with resected solid tumors and in combination with pembrolizumab in subjects with unresectable solid tumors (Keynote-603). J. Glob. Oncol. 2019, 5, 93. [CrossRef] 
185. Zanganeh, S.; Hutter, G.; Spitler, R.; Lenkov, O.; Mahmoudi, M.; Shaw, A.; Pajarinen, J.S.; Nejadnik, H.; Goodman, S.; Moseley, M.; et al. Iron oxide nanoparticles inhibit tumour growth by inducing pro-inflammatory macrophage polarization in tumour tissues. Nat. Nanotechnol. 2016, 11, 986-994. [CrossRef]

186. Pfannenstiel, L.W.; Lam, S.S.; Emens, L.A.; Jaffee, E.M.; Armstrong, T.D. Paclitaxel enhances early dendritic cell maturation and function through TLR4 signaling in mice. Cell. Immunol. 2010, 263, 79-87. [CrossRef]

187. Graziani, S.R.; Vital, C.G.; Morikawa, A.T.; Van Eyll, B.M.; Fernandes Junior, H.J.; Kalil Filho, R.; Maranhão, R.C. Phase II study of paclitaxel associated with lipid core nanoparticles (LDE) as third-line treatment of patients with epithelial ovarian carcinoma. Med. Oncol. 2017, 34, 151. [CrossRef]

188. Shen, C.; Frakes, J.; Weiss, J.; Caudell, J.J.; Hackman, T.G.; Akulian, J.A.; El-Haddad, G.; Hu, Y.; Dixon, R.; Pearson, A.T.; et al. Phase I study of NBTXR3 activated by radiotherapy in patients with advanced cancers treated with an anti-PD-1 therapy. J. Clin. Oncol. 2020, 38, TPS3173. [CrossRef]

Publisher's Note: MDPI stays neutral with regard to jurisdictional claims in published maps and institutional affiliations.

(C) 2020 by the authors. Licensee MDPI, Basel, Switzerland. This article is an open access article distributed under the terms and conditions of the Creative Commons Attribution (CC BY) license (http://creativecommons.org/licenses/by/4.0/). 